Article

\title{
A Survey of Regional-Scale Blocking Patterns and Effects on Air Quality in Ontario, Canada
}

\author{
Frank Dempsey \\ Environmental Monitoring and Reporting Branch, Ontario Ministry of Environment, Etobicoke, ON M9P 3V6, \\ Canada; frank.dempsey@ontario.ca
}

Received: 10 April 2018; Accepted: 6 June 2018; Published: 12 June 2018

\begin{abstract}
Blocking weather patterns cause persistent weather situations that alter typical wind and circulation patterns which may result in stagnant weather conditions at the surface and potentially adverse conditions that affect society, such as extended warmth, drought, precipitation or fog. One problem that may develop is adverse concentrations of air pollutants in populated regions that may persist for several days or longer. This study looks for possible correlation between blocking patterns and air quality episodes in southern Ontario, Canada. The method used was examination of various cases of air quality episodes. The meteorological details of these examples were examined to determine possible correlations with blocking patterns. Results of the comparisons revealed that various types of blocking patterns correlated with worsening air quality episodes in various regions of southern Ontario. The conclusion is that some large-scale as well as regional-scale blocking patterns may cause adverse air quality in different cities or regions of the province during any month, and forecasters need to be vigilant for these patterns.
\end{abstract}

Keywords: air quality; block pattern; ozone; PM2.5; synoptic meteorology

\section{Introduction}

Synoptic-scale blocking flow patterns, characterized by nearly stationary cyclones or anticyclones, cause stagnant weather patterns persisting for periods of several days or longer over a specific region which may result in unusually extended periods of persistent weather conditions close to a high or a low pressure region, as well as anomalous moisture transport over other regions [1]. Worsening air quality is one of the possible effects when a stagnant airmass remains over a region. Generally, northern hemisphere blocking anticyclones interrupt the midlatitude westerly jet and cause the eastward progression of synoptic systems to be diverted to the north or south of the anticyclone. A significant result is the poleward movement of low potential vorticity air from a subtropical source region east of a meridionally-elongated quasi-stationary trough, resulting in strengthening of the anticyclone. Another result is development of anomalous easterly flow south of the anticyclone.

Blocking circulation patterns preferentially form in particular regions due to resonant forcing with orographic and surface temperature features, such as the Rocky Mountain range and the east and west coasts of North America [2], and during particular seasons (such as winter-spring in the eastern Pacific and north Atlantic sectors) [3] but may form during any month. Blocks may be seen as a quasi-stable state of the atmosphere associated with planetary wave resonance in response to a specific forcing and were described by [4] as Rossby wavetrains initiated by major mountain ranges, splitting into northern and southern wavetrains that become out of phase over a longitude separation of about $60-80$ degrees downstream of the mountain range. Block patterns may persist longer than the constituent cyclones and anticyclones because of momentum transfer from transient eddies upstream of the block. Due to this eddy forcing, upstream cyclogenesis may enhance downstream blocking anticyclone formation by providing energy and vorticity. 
Numerous varying factors affect the blocking patterns that influence weather over eastern North America including ocean thermal and circulation anomalies and oscillations in the northern Pacific and Atlantic oceans, degree of ocean-atmosphere coupling, surface snow or ice cover, stratospheric and polar vortex circulations, and volcanic eruptions. North Atlantic blocking anticyclones tend to form near Greenland and the development of these and other high-latitude blocking anticyclones are related to patterns of temperature and pressure variations including ocean temperature variations such as the meridional overturning circulation and the Atlantic Multidecadal Oscillation [5,6], North Atlantic Oscillation [7], El Nino-Southern Oscillation [1,3,8], phase of the Madden-Julian Oscillation [9,10], solar forcing [11] and stratospheric variability [12]. In addition to these causes of variations in ocean temperatures, other factors that affect sea surface temperatures include effects of volcanic eruptions, warming induced by greenhouse gases $[13,14]$, cloud cover $[15,16]$ and near-surface mixing caused by atmospheric storminess and winds [17]. The importance of blocking patterns on persistent weather events might change in the future if arctic amplification and rapid arctic warming results in increasing incidences of blocking $[18,19]$ or might not change if arctic amplification has no significant effect $[20,21]$. The variability in location and duration of blocks that affect North America contributes to making forecasting the onset and dissolution of blocking patterns a challenge for numerical guidance.

While the original definition of a blocking pattern [22] was based on splitting of the westerly current into two branches extending over a longitude range of more than 45 degrees and persisting for more than 10 days, later criteria used in the published literature have used smaller longitude ranges and durations [23,24], $500 \mathrm{hPa}$ geopotential height (GPH) anomaly exceeding a threshold value for a minimum duration [25], or existence of easterlies at the $500 \mathrm{hPa}$ level between 40-60 degrees north $[26,27]$. More recent blocking indices have been defined and used by various researchers for creating algorithms to automate the identification of blocks in the climatology dataset. GPH or GPH anomaly fields, typically at the 700, 500 or $250 \mathrm{hPa}$ levels, are generally used. In this study, the $500 \mathrm{hPa}$ level GPH was used because it sufficiently illustrates the blocking pattern, and visual pattern recognition with physical and synoptic intuition provided by the author's daily forecasting perspective provides a reasonable identification of blocking patterns on various size scales.

As well as the hemispheric blocking patterns that have long been an active research area, regional-scale blocking patterns also cause local stagnation or other conditions that may result in adverse weather events over populated areas. Effects of blocking patterns on regional weather events and effects of weather factors on local air quality concentrations in various regions have been documented and are recognized and applied by air quality forecasters. For example, McKendry [28] showed how daily maximum ozone $\left(\mathrm{O}_{3}\right)$ concentrations were significantly modulated by the synoptic-scale atmospheric patterns in Vancouver, British Columbia, Canada. Shahgedanova et al. [29] showed how high concentrations of carbon monoxide (CO) and nitrogen dioxide $\left(\mathrm{NO}_{2}\right)$ in Moscow were affected by synoptic weather patterns in Russia. Jiang et al. [30] showed that blocking weather patterns affected $\mathrm{NO}_{2}$ concentrations in Auckland, New Zealand by altering the transport of oceanic air.

Worsening air quality may result from increasing concentrations of some or all of $\mathrm{O}_{3}$, fine particles (PM2.5), or $\mathrm{NO}_{2}$. Each is a pollutant because it is an irritant for the respiratory tract and eyes [31]. Ground-level $\mathrm{O}_{3}$ (not to be confused with stratospheric $\mathrm{O}_{3}$ ) is created from photochemical reactions involving oxides of nitrogen and volatile organic compounds in sunlight. Specific details about these pollutants can be found in $[32,33]$ and a brief overview of the significant chemistry involving $\mathrm{NO}_{2}$ and $\mathrm{O}_{3}$ is included in the supplement. $\mathrm{O}_{3}$ hourly concentrations greater than $80 \mathrm{ppb}$ are significant enough to be a respiratory irritant and the 1-h Ambient Air Quality Criterion in Ontario is $80 \mathrm{ppb}$. Nitrogen oxides include $\mathrm{NO}_{2}$ and nitric oxide (NO) and are produced by combustion processes (such as used in heating and transportation equipment) as well as other processes. PM2.5 exists as a mixture of solid particles and liquid droplets including aerosols, smoke, fumes, dust and pollen. Primary emission sources of PM2.5 include combustion sources used in transportation, power generation and industrial facilities. In addition to primary sources, secondary organic aerosols get produced by gas-to-particle conversion processes acting on emitted biogenic hydrocarbons and their oxidation products, followed 
by changes in size and composition. Organic compounds with lower vapor pressures that can condense onto nuclei may be formed from oxidation of VOCs as well as by condensation or evaporation of vapor-phase compounds, coagulation with other particles, or activation and growth in the presence of moisture. PM2.5 formation may be enhanced in air with higher relative humidity. These are pollutants that may have a significant impact on health and are measured at air quality monitoring stations. Other pollutants that are measured at specific air quality monitoring sites include sulfur dioxide $\left(\mathrm{SO}_{2}\right)$ and $\mathrm{CO}$, but these gases are significant only in some locations where local industrial sources (such as smelters) may occasionally cause pollutant concentrations noticeably above background levels.

In Ontario, meteorology is affected primarily by the midlatitude westerly jet and the eastward progression of cyclones, anticyclones, and fronts across eastern North America, and significant modification by the three Great Lakes surrounding southern Ontario often affects local weather and air quality [34]. Local air pollutant concentrations are mainly determined by the combination of emissions, chemistry and local meteorology, but an estimated $55 \%$ of air pollution impacts result from transboundary flow of emissions from the United States [35]. Blocking weather patterns cause adverse air pollutant concentrations in southern Ontario by altering circulation patterns that affect transport of pollutants to Ontario and that affect winds, dispersion conditions and mixing of the boundary layer. To the author's knowledge, no survey or summary of effects of blocking patterns on air pollutant concentrations in Ontario has been published.

This manuscript is a survey of typical examples of regional-scale block patterns that disrupt the typical flow of weather systems over southern Ontario and that have caused adverse air quality conditions in populated regions. The case studies are presented using meteorological charts and time-series plots of pollutant concentrations (obtainable from existing archives and databases) to provide examples of the stagnant regional-scale weather patterns which may cause adverse effects on air quality and dispersion conditions. Supplementary charts of weather or ocean conditions provide more illustrations of the weather conditions than the one or two figures in each example in the manuscript. The main block effects include a stationary summertime ridge over Ontario that caused increasing $\mathrm{O}_{3}$ and PM2.5 concentrations, stationary ridge patterns during mid-autumn and during mid-winter that resulted in increasing PM2.5 concentrations, a block pattern that caused northern forest fire smoke to anomalously flow southwestward over populated regions, and a retrograde ridge that moved westward and combined with local lake effects to cause high $\mathrm{O}_{3}$ concentrations. Results are summarized in a table listing the main types of blocking patterns that most commonly affect air quality and their significant effects on pollutant concentrations in populated regions of Ontario.

\section{Data and Methods}

The source of blocking examples is the author's experience as an operational forecaster of Ontario's air quality during the 17-year period of 2000-2017. Daily forecasting resulted in close attention paid to poorly forecastable periods when blocking weather patterns developed. The examples in this survey that were selected to illustrate the types of block effects include a description of the meteorological situation relevant to each example, followed by the significant effect on air quality in populated regions.

Archive meteorological charts for illustrating the relevant meteorology in each case study have been plotted in the manuscript or supplement using NCEP/NCAR (US National Centers for Environmental Prediction/National Center for Atmospheric Research) Reanalysis data [36], North American Regional Reanalysis (NARR) data, the websites of NOAA (National Oceanic and Atmospheric Administration) Earth System Research Laboratory (ESRL) Physical Sciences Division and the Real-time Environmental Applications and Display System (READY) of the NOAA Air Resources Laboratory (ARL). The main meteorological charts used are mean sea level pressure (MSLP) and GPH at the $500 \mathrm{hPa}$ level. Other data were used to plot charts relevant to the cases including sea surface temperatures from NOAA National Environmental Satellite, Data and Information Service (NOAA/NESDIS), NOAA Great Lakes Environmental Research Laboratory (GLERL), NASA Worldview satellite imagery showing wildfire active hotspots and smoke plumes, GOES satellite 
imagery, and upper air sounding data from archives at the website of the University of Wyoming. Pollutant concentration data were accessed from the data portal provided by the Ontario Ministry of Environment and Climate Change (MOECC) online at www.airqualityontario.com. Locations of the MOECC air quality monitoring stations are shown in Figure 1.

Several locations, Hamilton and Toronto, have been used in most of the examples for consistency and they are significant population centers. Several other locations have been selected to represent air quality effects on populated regions in other parts of Ontario, including Mississauga (between Toronto and Hamilton), Belleville near the northeastern shore of Lake Ontario, Windsor and Sarnia in southwestern Ontario, Cornwall and Ottawa in eastern Ontario, Sudbury and North Bay in northeastern Ontario, and several other widely spaced locations (Dorset, Barrie, Kingston and Oshawa) to illustrate the widespread impact of the wildfire smoke example of 1 July 2013. Geographic coordinates and populations of the locations are shown in Table 1 along with notes about their closeness to urban or rural environments and tendency to be influenced by lake breeze effects.

Instrumental details to note include instrument models and data precision. $\mathrm{O}_{3}$ measurements were made by the Thermo Environmental Instruments Model $49 \mathrm{C} / \mathrm{I}$ dual-cell UV photometric $\mathrm{O}_{3}$ analyzer. Errors are $+/-1 \mathrm{ppb} . \mathrm{NO}_{2}$ measurements were made by the Thermo Environmental Instruments Model $42 \mathrm{C} / \mathrm{I}$. Errors are $+/-0.4 \mathrm{ppb}$. Measurements of PM2.5 were analyzed until the end of 2012 using the Thermo Scientific TEOM 1400AB/SES Tapered Element Oscillating Microbalance (TEOM) instrument operating at a temperature of $30^{\circ} \mathrm{C}$ with a Sample Equilibration System (SES) and errors are $<2$ micrograms per cubic meter. From 2013, measurements of PM2.5 have been made using the Thermo Scientific Model 5030 SHARP Synchronized Hybrid Ambient Real-time Particulate monitor. Errors are $+/-2$ micrograms per cubic meter for the range $<80$ micrograms per cubic meter and $+/-5$ micrograms per cubic meter for the range $>80$ micrograms per cubic meter. Data shown in the charts are not $100 \%$ complete because of occasional missed hourly data reports due to instrument maintenance or service interruptions.

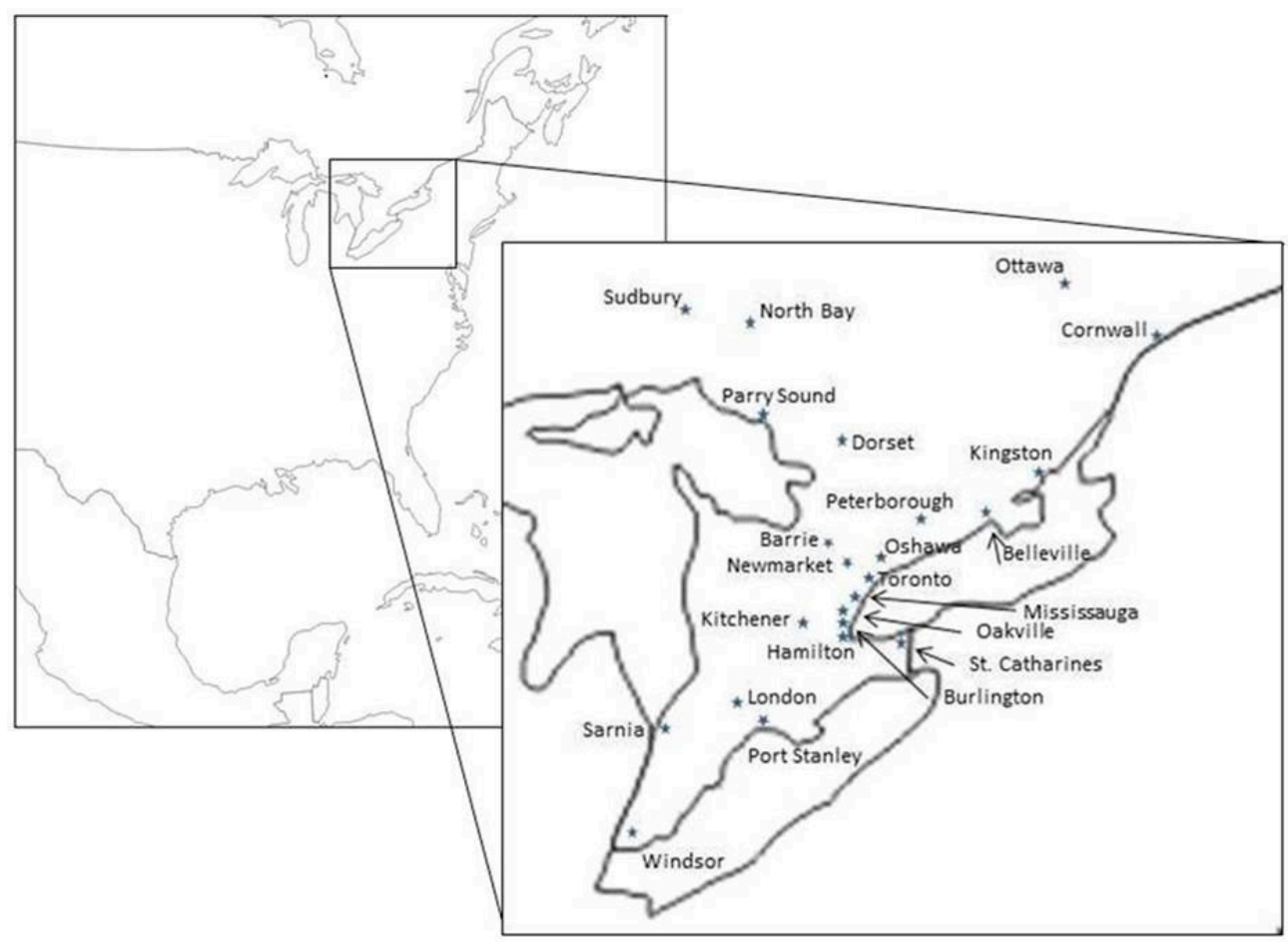

Figure 1. Locations of the MOECC air quality monitoring stations. 
Table 1. Air quality monitoring locations in this survey.

\begin{tabular}{|c|c|c|c|c|c|}
\hline City & Latitude & Longitude & $\begin{array}{l}\text { Population (2016) } \\
\text { (Data from } \\
\text { Statistics Canada) }\end{array}$ & $\begin{array}{c}\text { Urban or Rural } \\
\text { Environment near } \\
\text { Monitoring Station }\end{array}$ & $\begin{array}{c}\text { Affected by } \\
\text { Lake Breezes? }\end{array}$ \\
\hline Barrie & $44^{\circ} 22^{\prime} 56.5^{\prime \prime}$ & $-79^{\circ} 42^{\prime} 08.3^{\prime \prime}$ & 141,000 & urban & $\mathrm{N}$ \\
\hline Belleville & $44^{\circ} 09^{\prime} 01.9^{\prime \prime}$ & $-77^{\circ} 23^{\prime} 43.8^{\prime \prime}$ & 51,000 & urban & Y \\
\hline Cornwall & $45^{\circ} 01^{\prime} 04.7^{\prime \prime}$ & $-74^{\circ} 44^{\prime} 06.8^{\prime \prime}$ & 47,000 & urban & $\mathrm{N}$ \\
\hline Dorset & $45^{\circ} 13^{\prime} 27.4^{\prime \prime}$ & $-78^{\circ} 55^{\prime} 58.6^{\prime \prime}$ & $<1000$ & rural & $\mathrm{N}$ \\
\hline Hamilton & $43^{\circ} 15^{\prime} 28.0^{\prime \prime}$ & $-79^{\circ} 51^{\prime} 42.0^{\prime \prime}$ & 537,000 & urban & Y \\
\hline Kingston & $44^{\circ} 13^{\prime} 11.5^{\prime \prime}$ & $-76^{\circ} 31^{\prime} 16.1^{\prime \prime}$ & 124,000 & urban & $\mathrm{Y}$ \\
\hline Mississauga & $43^{\circ} 32^{\prime} 49.1^{\prime \prime}$ & $-79^{\circ} 39^{\prime} 31.3^{\prime \prime}$ & 722,000 & urban & Y \\
\hline North Bay & $46^{\circ} 19^{\prime} 23.5^{\prime \prime}$ & $-79^{\circ} 26^{\prime} 57.4^{\prime \prime}$ & 52,000 & urban & $\mathrm{N}$ \\
\hline Oshawa & $43^{\circ} 56^{\prime} 45.4^{\prime \prime}$ & $-78^{\circ} 53^{\prime} 41.7^{\prime \prime}$ & 159,000 & urban & $\mathrm{Y}$ \\
\hline Ottawa & $45^{\circ} 26^{\prime} 03.6^{\prime \prime}$ & $-75^{\circ} 40^{\prime} 33.6^{\prime \prime}$ & 934,000 & urban & $\mathrm{N}$ \\
\hline Sarnia & $42^{\circ} 58^{\prime} 56.2^{\prime \prime}$ & $-82^{\circ} 24^{\prime} 18.3^{\prime \prime}$ & 72,000 & urban & $\mathrm{Y}$ \\
\hline Sudbury & $46^{\circ} 29^{\prime} 31.0^{\prime \prime}$ & $-81^{\circ} 00^{\prime} 11.2^{\prime \prime}$ & 22,000 & urban & $\mathrm{N}$ \\
\hline Toronto & $43^{\circ} 39^{\prime} 46.7^{\prime \prime}$ & $-79^{\circ} 23^{\prime} 17.2^{\prime \prime}$ & $2,732,000$ & urban & $\mathrm{Y}$ \\
\hline Windsor & $42^{\circ} 18^{\prime} 56.8^{\prime \prime}$ & $-83^{\circ} 02^{\prime} 37.2^{\prime \prime}$ & 217,000 & urban & Y \\
\hline
\end{tabular}

\section{Results and Discussion}

The examples of each type of blocking effect are shown below with the minimum graphic charts to illustrate the pattern, followed by some discussion for each case. More detailed illustrations appear in the Supplement Materials.

\subsection{Example of 22-25 June 2003}

\subsubsection{Introduction}

In this example, a blocking pattern over the Atlantic Ocean caused a high pressure ridge to become stationary over southern Ontario for several days, causing a prolonged period of warm and sunny days with a stagnant airmass that became progressively more polluted each day with increasing concentrations of $\mathrm{O}_{3}$ and PM2.5.

\subsubsection{Synoptic Description}

An upper level trough at the $500 \mathrm{hPa}$ level moved eastward from southern Ontario during 20-21 June and split into a northern and southern portion. The northern trough continued to move eastward and then became quasi-stationary near southern Greenland, while the southern trough remnant remained over the northeastern US for several days and was blocked from eastward movement by the large closed low south of Greenland. A large ridge was situated over western Europe and a large ridge was over the tropical Atlantic, south of the low over the north Atlantic. Warm sea surface temperatures over the tropical Atlantic waters (illustrated in the supplement) contributed to building the ridge aloft over the tropical Atlantic. Following the eastward movement of the trough, a ridge spread eastward over the eastern US and Great Lakes region during 21-25 June. The trough over the northeastern US eventually moved northeastward from the Atlantic coast during 23-24 June.

The sequence of daily charts showing the $500 \mathrm{hPa}$ synoptic-scale pattern in Figure 2 shows the mid-Atlantic ridge and the slow eastward movement of the low near and east of the Atlantic coast. The blocked ridge over the southeastern US and Great Lakes area formed an omega block configuration over Ontario with the low pressure troughs east and west of the ridge contributing to form a stable pattern that persisted for several days. The surface pressure pattern featured a high pressure ridge over southern Ontario during the period from 21-25 June (illustrated in the supplement). The ridge caused winds to become southwesterly during the afternoon and temperatures increased above $30^{\circ} \mathrm{C}$ on 23 June at Windsor (in southwestern Ontario). These conditions persisted until the afternoon of 26 June, when the passage of a cold front caused a change in airmass followed by lower pollutant concentrations. The cold front caused pollutant concentrations to decrease by replacing the airmass 
with a less polluted and cooler airmass from northern source regions, as well as by causing increasing dispersion of the lower atmosphere with increasing wind speeds and vertical mixing due to advection of cooler air.

\subsubsection{Discussion}

Ozone hourly concentrations increased above $80 \mathrm{ppb}$ at various air quality stations in southern, eastern, and northeastern Ontario during 22-26 June and have been plotted in Figure 3. The maximum hourly reading was $149 \mathrm{ppb}$ at Belleville during the afternoon of 25 June. After 26 June, $\mathrm{O}_{3}$ concentrations were significantly lower and commensurate with a change of airmass. For a wider perspective, a chart of maximum daily 1-h $\mathrm{O}_{3}$ concentrations during the period May-August 2003 is shown (in the supplement) and shows that $\mathrm{O}_{3}$ concentrations increased above Ontario's $80 \mathrm{ppb}$ Ambient Air Quality Criterion several times during the summer at most of the monitoring stations, and that the 22-25 June episode was a relatively extended episode of high $\mathrm{O}_{3}$ concentrations. Concentrations of PM2.5 also increased significantly at various locations. The concentrations at three of the monitoring stations, Hamilton, Toronto and Belleville, appear plotted in Figure 4 and show that concentrations increased above 50 micrograms per cubic meter during 25-26 June and then decreased significantly when a cleaner airmass moved over southern Ontario. As well, $\mathrm{NO}_{2}$ concentrations, shown in Figure 5, increased significantly and contributed to the polluted airmass during several days.

Characteristics of the block that contributed to deteriorating air quality were the stagnation pattern resulting in the ridge remaining over southern Ontario and causing a prolonged period of mostly sunny skies, very warm temperature, high dewpoint and light southwesterly winds. Temperatures at the $850 \mathrm{hPa}$ level increased and caused a capping inversion above the boundary layer that restricted vertical mixing and allowed the boundary layer to gradually become more polluted each successive day. The upper air soundings from Detroit MI on the morning and evening of 23 June (illustrated in the supplement) show a strong low-level inversion during the morning (remaining from a nocturnal inversion which persisted for several hours after sunrise), while the evening sounding shows a strong capping inversion at the $850 \mathrm{hPa}$ level. Similar soundings for Buffalo NY (illustrated in the supplement) also show low-level inversions. Surface observations for Windsor, Ontario are shown in the NARR meteogram in the supplement. Key points relevant to stagnation and deteriorating air quality include the generally light winds, mostly clear skies (sunny during the daytime and clear skies during the nights, allowing radiation-nocturnal inversions to form at night with very low planetary boundary layer heights by morning), very warm afternoon temperatures near the surface, and increasing temperature at the $850 \mathrm{hPa}$ level (contributing to strengthening of the capping inversion from day to day).

\subsubsection{Summary}

A stable omega block configuration over eastern North America caused a ridge to become blocked over southern Ontario and the eastern US for a period of about four days. The blocked ridge caused weather conditions suitable for $\mathrm{O}_{3}$ and PM2.5 concentrations to increase each day and to cause adverse air quality in populated cities until the ridge moved eastward and a weather front provided a change in airmass. 

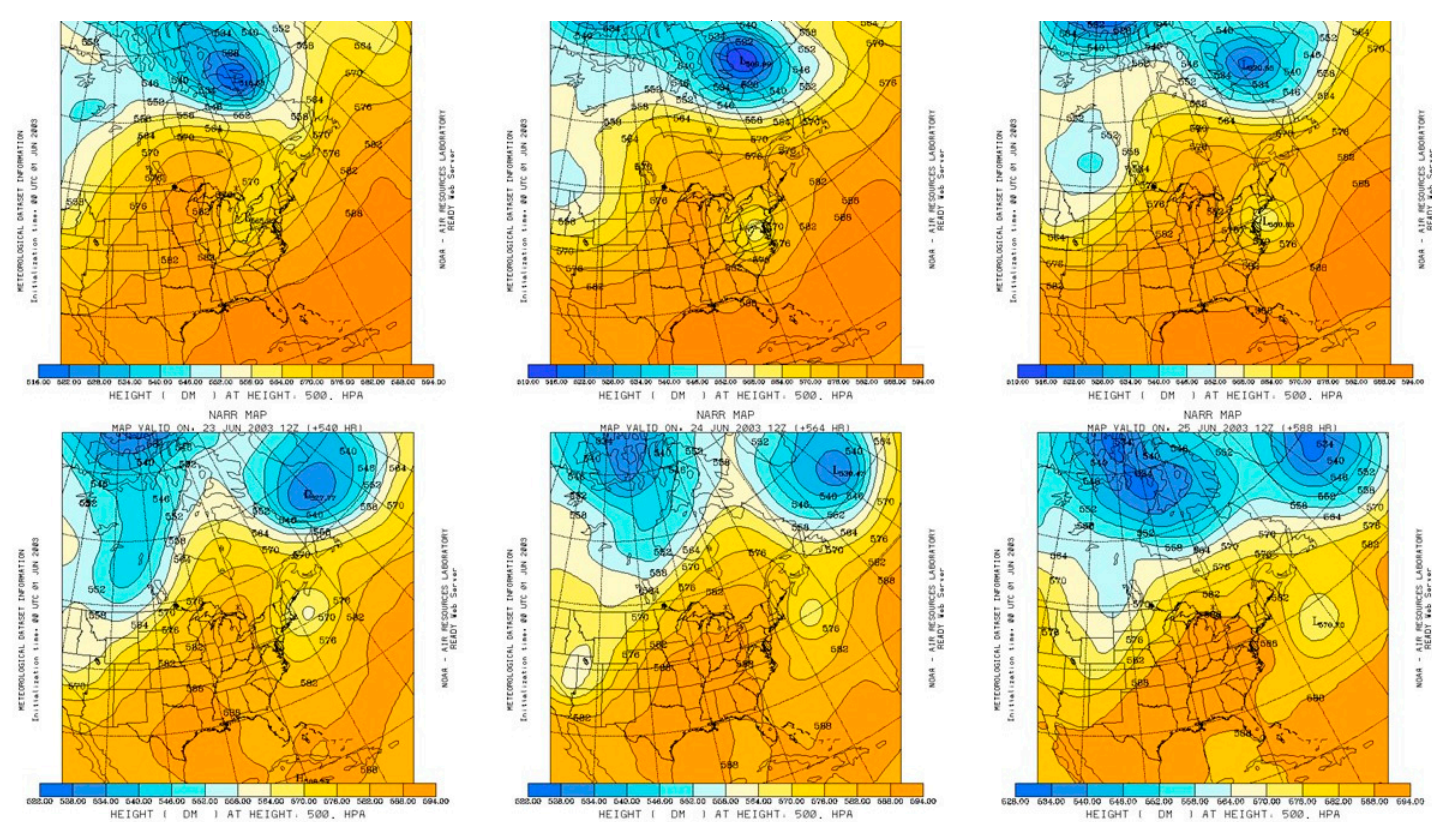

Figure 2. Daily 500 hPa GPH from June 20 (upper left) to 25 (lower right), 2003. Credit: NOAA ARL (website: http://www.arl.noaa.gov/index.php).

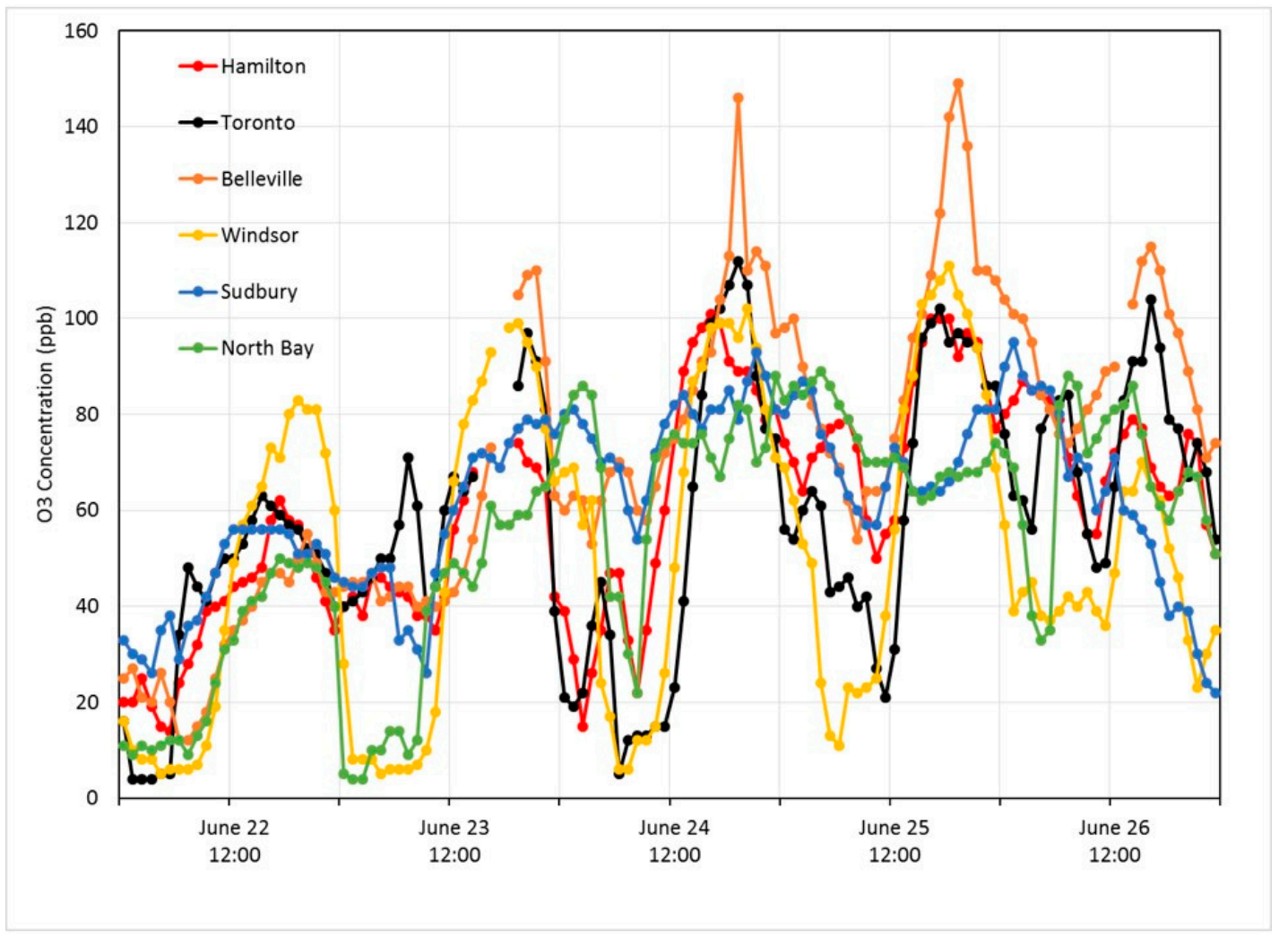

Figure 3. $\mathrm{O}_{3}$ hourly concentrations, 22-26 June 2003. Dates are shown at EDT (local time) 12:00. 


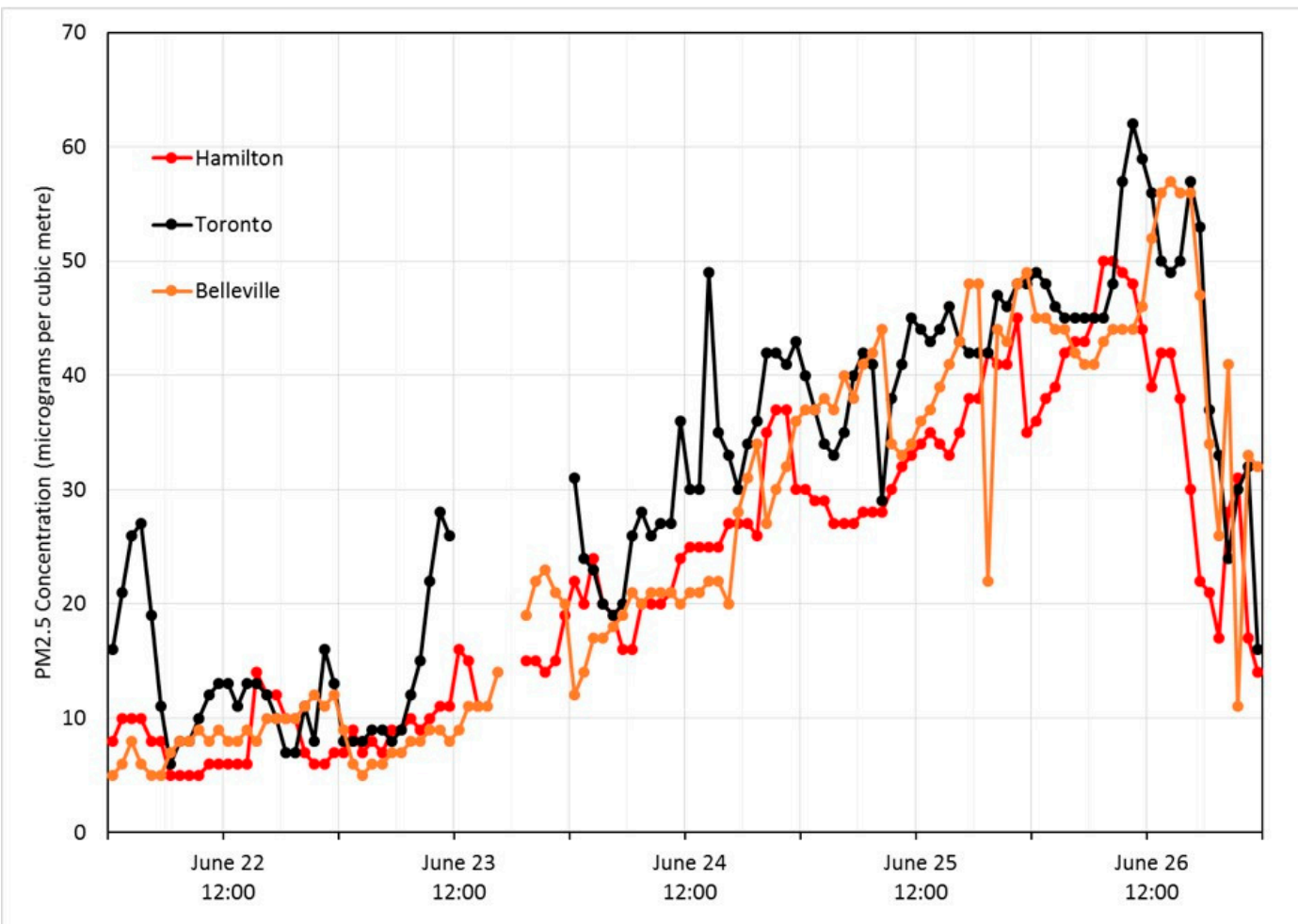

Figure 4. PM2.5 hourly concentrations at Windsor and Toronto during 22-26 June 2003. Dates are shown at EDT (local time) 12:00.

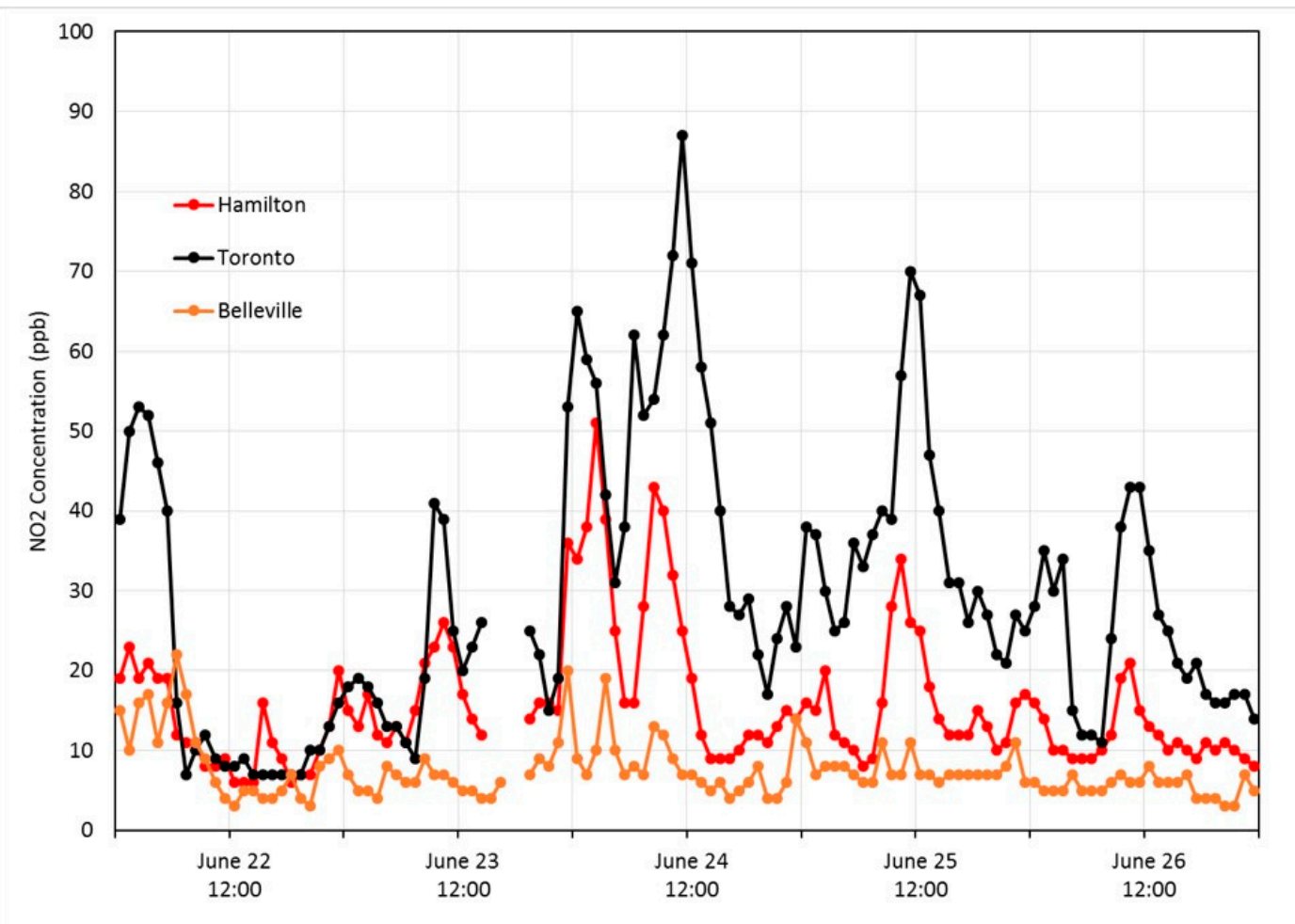

Figure 5. $\mathrm{NO}_{2}$ hourly concentrations at Windsor and Toronto during 22-26 June 2003. Dates are shown at EDT (local time) 12:00. 


\subsection{Example of 2-7 February 2005}

\subsubsection{Introduction}

A ridge at upper and surface levels became blocked over southern Ontario for several days during February. Resulting stagnation allowed concentrations of PM2.5 to increase and cause adverse air quality for numerous populated areas in southern Ontario during the first week of February.

\subsubsection{Synoptic Description}

At the $500 \mathrm{hPa}$ level, a ridge had been situated over the northeastern Atlantic Ocean since late January. The ridge moved westward to the central Atlantic during the first week of February. A trough over eastern Canada during late January expanded eastward to a mean trough position over the western Atlantic, east of the US Atlantic coast, during the first week of February. Over the eastern US, a ridge spread northward and strengthened during the period of 1-5 February and then gradually weakened and was eventually replaced by a trough that moved southeastward over the Great Lakes region during 8 February. The blocking ridge over the Atlantic caused the western Atlantic trough to remain quasi-stationary, and this caused the ridge over the eastern US and southern Ontario to stagnate. A chart showing the composite mean $500 \mathrm{hPa}$ GPH is shown in Figure 6 and the sequence showing the daily $500 \mathrm{hPa}$ patterns is shown in the supplement. The $500 \mathrm{hPa}$ level GPH mean composite anomaly during 2-5 February (illustrated in the supplement) shows the anomalous strength of the ridge over Ontario during this period. A chart showing the MSLP during 5 February is shown in Figure 7 and the surface high pressure ridge can be seen extending from the eastern US northeastward across southern Ontario. The pattern of daily MSLP during 1-6 February is shown in the supplement.

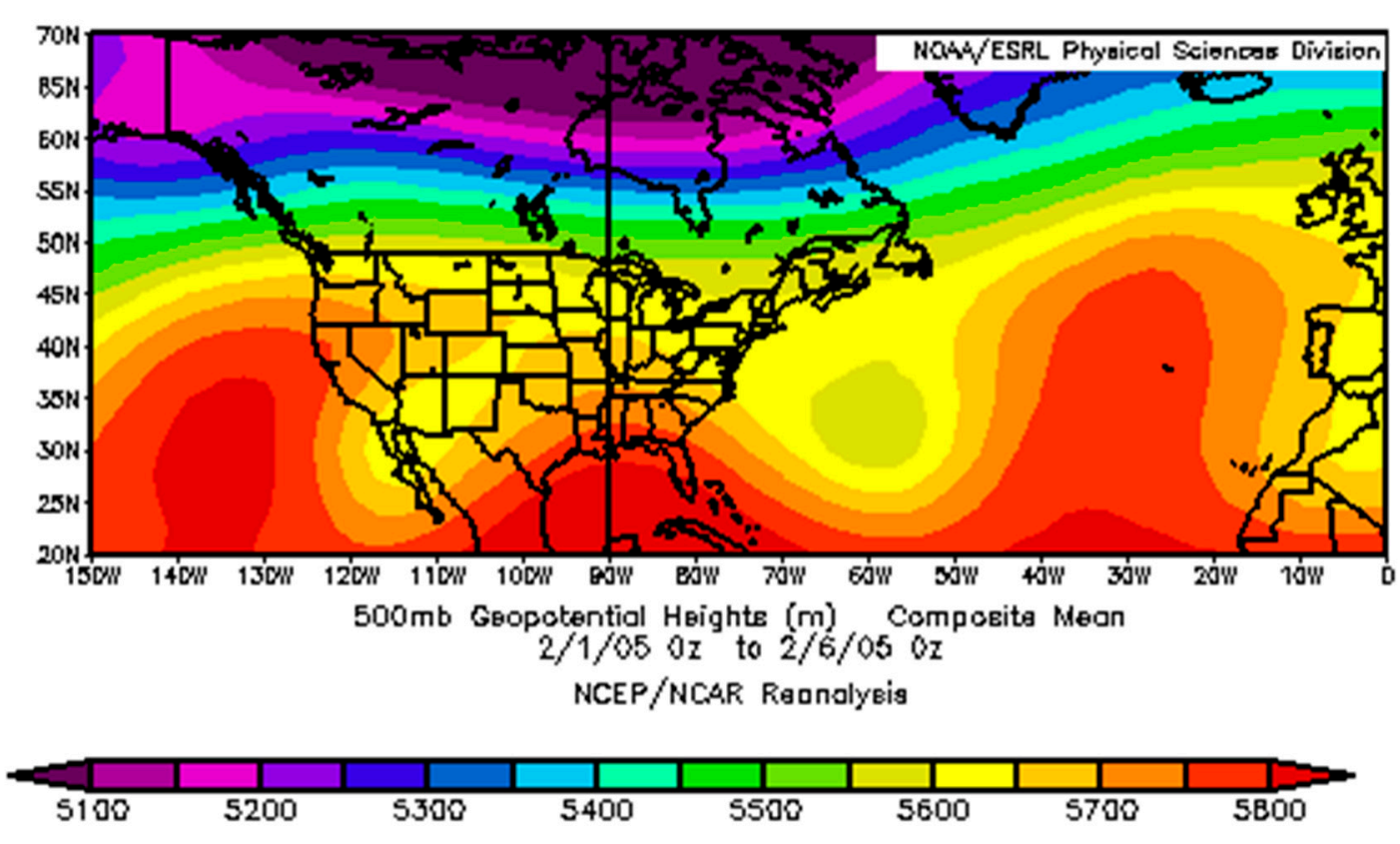

Figure 6. Composite 500 hPa GPH, 1-5 February 2005. Credit: NOAA ESRL PSD (website: http: //www.esrl.noaa.gov/psd/). 


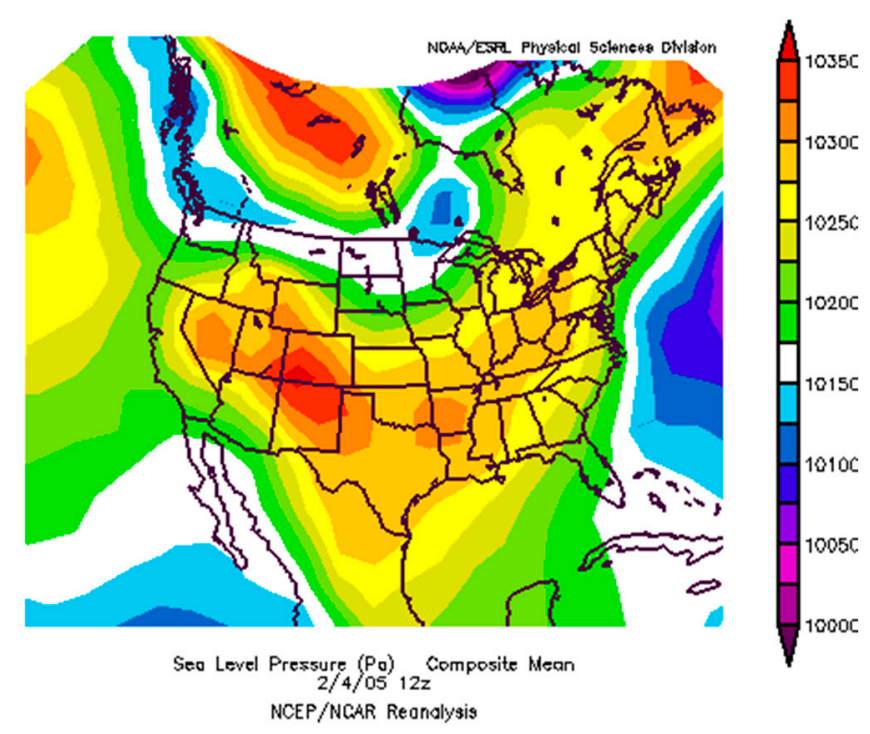

Figure 7. MSLP, 5 February 2005. Credit: NOAA ESRL PSD.

\subsubsection{Discussion}

Concentrations of PM2.5 began to increase during late January, during a period when light winds resulted below a low pressure trough which moved over Ontario. Maximum concentrations occurred during 4-5 February when the ridge was over southern Ontario, and then concentrations decreased sharply during 7 February. The PM2.5 daily maximum 1-h concentrations at various stations are shown in Figure 8 for the period 20 January-20 February. The month-long time period provides a perspective of the typical PM2.5 concentrations during the winter and the anomalous concentrations that developed during the blocking event. At Sarnia in southwestern Ontario, PM2.5 daily maximum 1-h concentrations increased from 22 micrograms per cubic meter during 31 January to 114 during 5 February and then decreased to 26 by 7 February. At Ottawa in eastern Ontario, PM2.5 daily maximum 1-h concentrations increased from 10 micrograms per cubic meter during 27 January to 57 during 7 February and then decreased to zero by 9 February. The weather conditions (illustrated in the supplement) for Sarnia for the period 1-4 February show the weakening high pressure ridge, light winds becoming southwesterly, increasing temperatures at the $850 \mathrm{hPa}$ level, and small temperature-dewpoint spread. All of these factors are favorable for growth of PM2.5 and weak dispersion in the boundary layer. Long-range transport may also have contributed precursors in the condition of light flow from the southwest that developed on the west side of the ridge. $\mathrm{NO}_{2}$ concentrations also increased significantly, in general correlation with PM2.5, and are shown in Figure 9. $\mathrm{O}_{3}$ did not increase significantly in this example and so is not shown here, but $\mathrm{O}_{3}$ concentrations typically do not increase significantly during the month of February. For example, the maximum hourly $\mathrm{O}_{3}$ concentration at Toronto during the period 20 January-20 February 2005 was 40 ppb (during 12 February).

Considerable variation among monitoring stations can be seen in Figure 8 resulting from differences in local geography (such as sloping terrain, forested or flat terrain, nearness to liquid or frozen lakes or rivers, and surrounding land use) and effects on local meteorology (such as wind speeds and directions, surface and air temperatures, and depth of the mixed layer) and resulting effects on dispersion and stagnation of the lowest layer of the atmosphere, as well as variations in proximity to emission sources (such as urban centers, industrial facilities, or vehicle traffic). The greatest concentration of PM2.5 was at Sarnia, and contributing factors include the location of the Sarnia monitoring station (in 2005) in a river valley, several hundreds of meters from the St. Clair River separating Ontario, Canada from Michigan, USA. This river valley location contributed to higher pollutant concentrations because of weak winds (which may have been stronger at surrounding, higher 
terrain) and possible exposure to emissions from nearby vehicle roadways, a nearby railway line, commercial shipping activity on the St. Clair River, and industrial and urban emissions from both Sarnia and nearby Port Huron, Michigan.

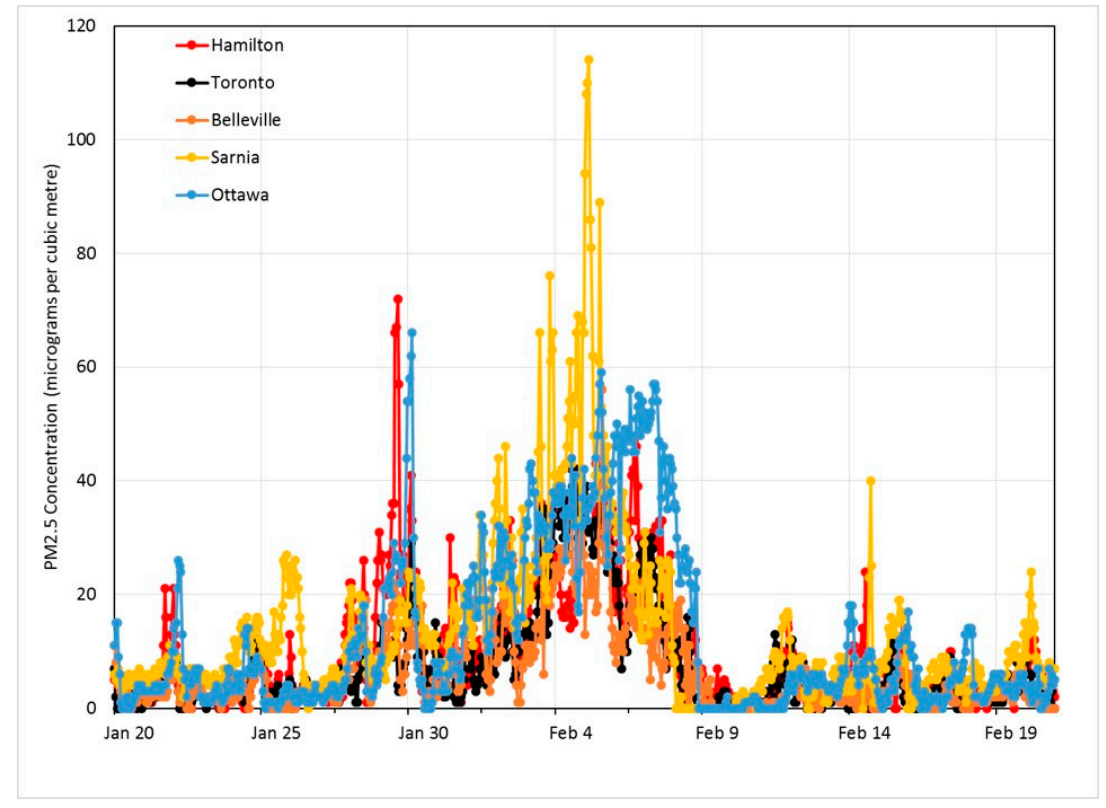

Figure 8. Daily maximum 1-h PM2.5 concentrations, 20 January-20 February 2005.

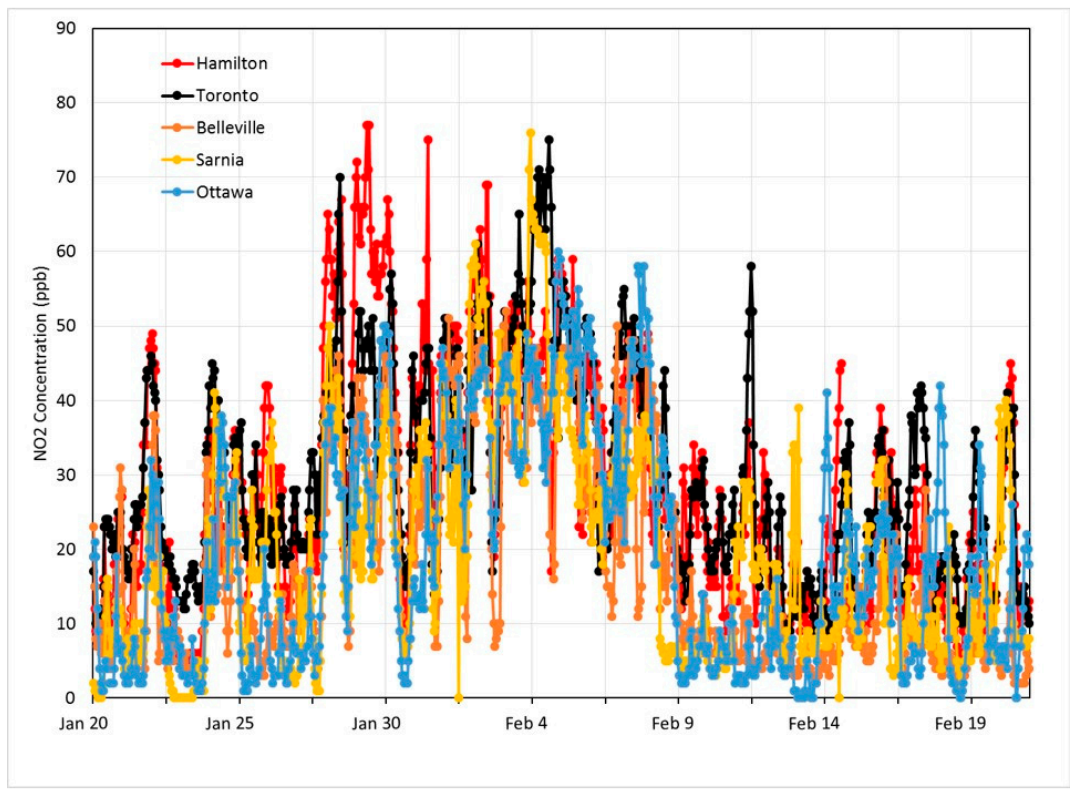

Figure 9. Daily maximum 1-h $\mathrm{NO}_{2}$ concentrations, 20 January-20 February 2005.

This is an example of a problem of stagnation during winter because during multi-day periods of light winds, boundary layer mixing and dispersion conditions can remain weak due to weak solar insolation and small differences in land-lake temperatures. In contrast, during the warm season, significant boundary layer mixing develops by mid-morning during most days due to convection caused by strong solar insolation and lake breeze formation (when temperatures over land become significantly warmer than lake surface temperatures) in the many populated areas affected by lake breeze circulations. 


\subsubsection{Summary}

A ridge became nearly stationary for several days over the southern Great Lakes region during the period 2-7 February and resulting stagnation allowed PM2.5 and $\mathrm{NO}_{2}$ concentrations to increase significantly and cause adverse air quality for several days at various cities in southern and eastern Ontario, likely due to a combination of long-range advection of precursors and local emissions in some locations.

\subsection{Example of 12 November 2010}

\subsubsection{Introduction}

In this example, a mesoscale high pressure ridge became blocked over southern Ontario and combined with local lake effects to cause stagnation during the morning of 12 November, which resulted in increasing concentrations of PM2.5 during most of the morning at various locations. Concentrations of $\mathrm{NO}_{2}$ also increased, while $\mathrm{O}_{3}$ concentrations did not increase noticeably (and are generally not significant during mid-November).

\subsubsection{Synoptic Description}

At the $500 \mathrm{hPa}$ level, a strong ridge was nearly stationary over the mid-Atlantic Ocean during the period 5-9 November in a strong omega block configuration. This caused a trough that moved eastward over Ontario during 6 November to become nearly stationary over and east of the Atlantic coast during the period 8-12 November. In turn, this trough caused a ridge that moved eastward to southern Ontario on 10 November to become nearly stationary for several days. The $500 \mathrm{hPa}$ pattern is shown in Figure 10. A surface high pressure ridge moved very slowly over southern Ontario and eastern Canada during the period 9-12 November. The ridge was effectively blocked from moving further eastward from eastern Canada by the trough at the Atlantic coast (illustrated in Figure 11). At the $850 \mathrm{hPa}$ level, a ridge was over southern Ontario during the morning of 12 November. Temperatures at $850 \mathrm{hPa}$ (illustrated in the supplement) show temperatures close to $10^{\circ} \mathrm{C}$ over southern Ontario. A weak frontal zone was over the central Great Lakes region during the morning and moved slowly across southern Ontario later during the afternoon of 12 November and overnight. The upper air sounding for Buffalo NY (illustrated in the supplement) shows a strong thermal inversion above the surface during the morning of 12 November. Also, several other details related to the stagnation are the warm Great Lakes surface temperatures (illustrated in the supplement) near $10^{\circ} \mathrm{C}$ around mid-November that resulted in minimal land-water temperature difference and mean sea-level pressure (illustrated in the supplement) with the high pressure ridge over the region.

\subsubsection{Discussion}

Concentrations of PM2.5 increased significantly during 12 November to a maximum of 56 micrograms per cubic meter at Hamilton and increased noticeably at other locations across southern and eastern Ontario (illustrated in Figure 12). $\mathrm{NO}_{2}$ concentrations increased to a lesser extent than PM2.5 and are shown in Figure 13. Factors contributing to the significant increase in pollutant concentrations included clear skies overnight, followed by fog that formed during the early morning and persisted until afternoon at both Hamilton and Toronto. (Fog was reported in the hourly observations at Hamilton airport CYHM from 11 November 22:00 EST (local time) until 12 November 13:00, and in the hourly observations at Toronto airport CYYZ from 12 November 06:00 until 12 November 13:00.) Several factors that contributed to cause a strong thermal and subsidence inversion over southern Ontario included subsidence caused by the high pressure ridge, a nocturnal radiation inversion associated with the clear night skies, and advection of warm air above the boundary layer (in southwesterly flow on the west side of the ridge axis). While temperatures at the $850 \mathrm{hPa}$ level were close to $10^{\circ} \mathrm{C}$, surface temperatures at Hamilton airport (CYHM) and Toronto airport (CYYZ) were much cooler, zero and $1^{\circ} \mathrm{C}$ respectively, at 7 am EST (UTC 12:00). The lake temperature and 
cooler season also may have contributed to the adverse air quality at locations near Lake Ontario. The relatively warm lake (close to $10^{\circ} \mathrm{C}$ ) resulted in a much smaller lake-land temperature difference during the afternoon and resulting lake breeze circulations were smaller than would occur during spring or early summer (when large lake-land temperatures typically cause robust lake breeze circulations). Weaker solar insolation than in summer, as well as the fog causing weaker insolation, also reduced the tendency for land surfaces to increase in temperature and this reduced the tendency for lake breeze circulations to develop. Weak pressure gradients and light winds (caused by the presence of the synoptic-scale ridge axis as well as the near absence of meso-scale circulations) resulted in minimum dispersion of the accumulated pollutants beneath the thermal inversion and contributed to the persistence of the high pollutant concentrations until afternoon.
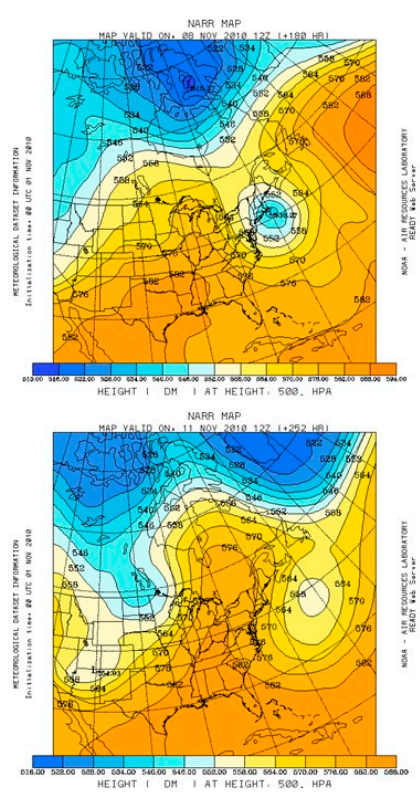
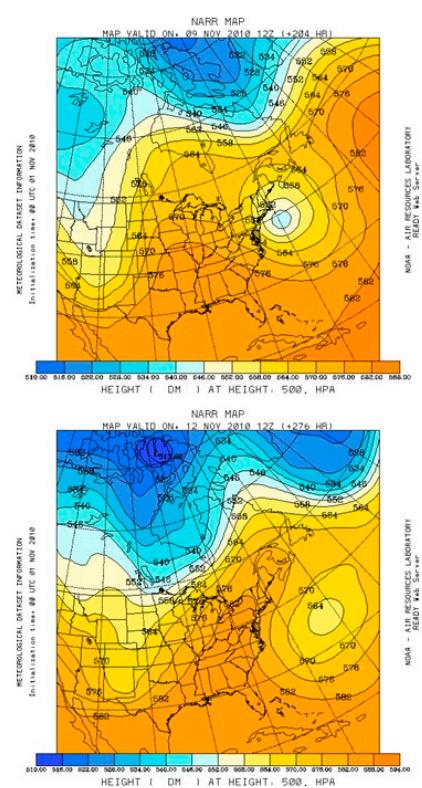
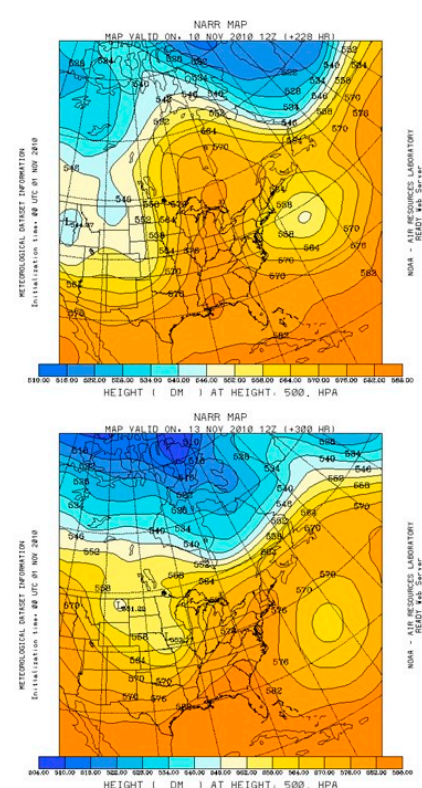

Figure 10. Pattern of $500 \mathrm{hPa}$ GPH from 8 November (upper left) to 13 November (lower right), 2010. Credit: NOAA ARL.
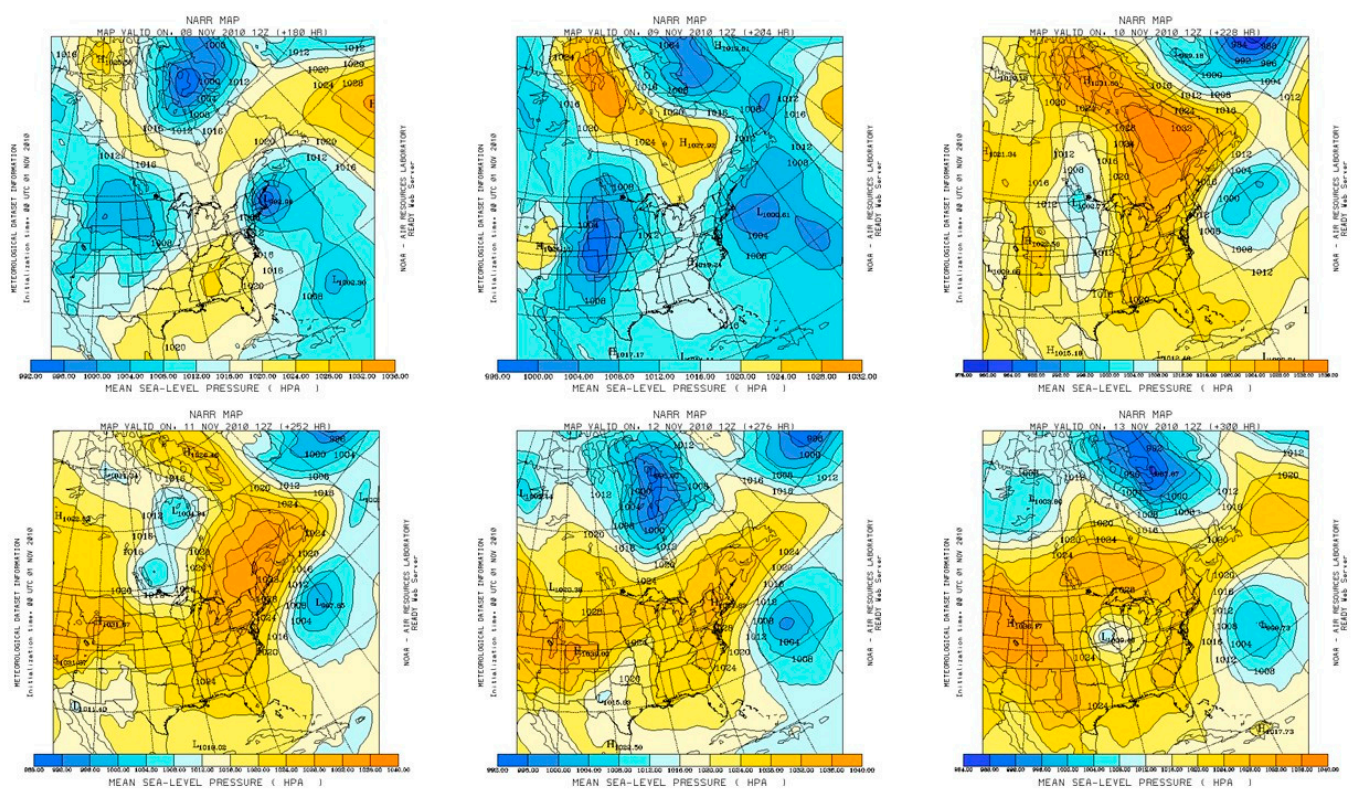

Figure 11. Pattern of MSLP, 8 November (upper left) to 13 November (lower right), 2010. Credit: NOAA ARL. 


\subsubsection{Summary}

A weak block pattern east of the Atlantic coast caused a strong and narrow high pressure ridge to become stationary over southern Ontario. Weak stagnation developed during 12 November and combined with seasonal lake and land temperature effects to allow concentrations of PM2.5 (and, to a lesser extent, $\mathrm{NO}_{2}$ ) to increase and cause adverse air quality conditions until a weak frontal zone moved across southern Ontario, followed by a change in airmass.

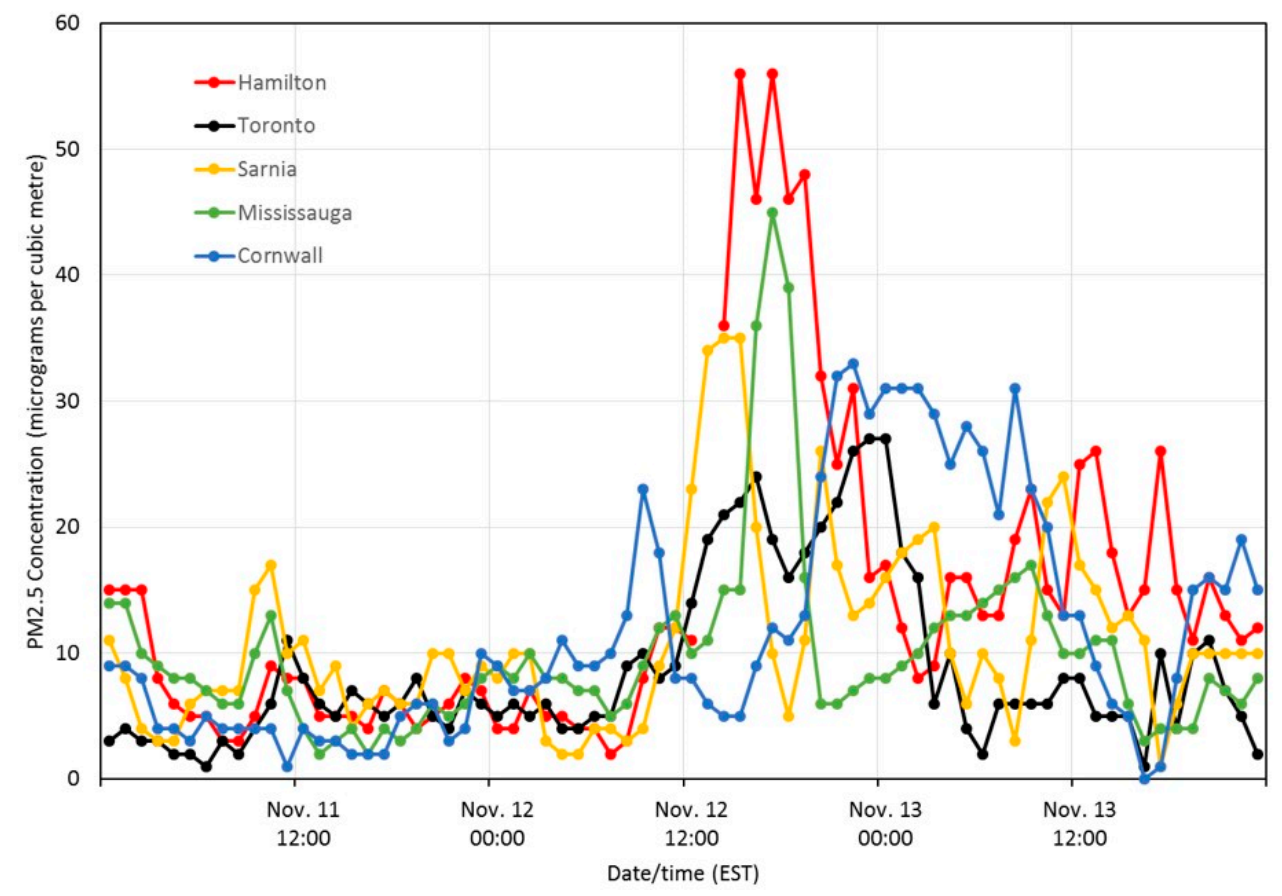

Figure 12. PM2.5 hourly concentrations at various locations, 11-13 November 2010.

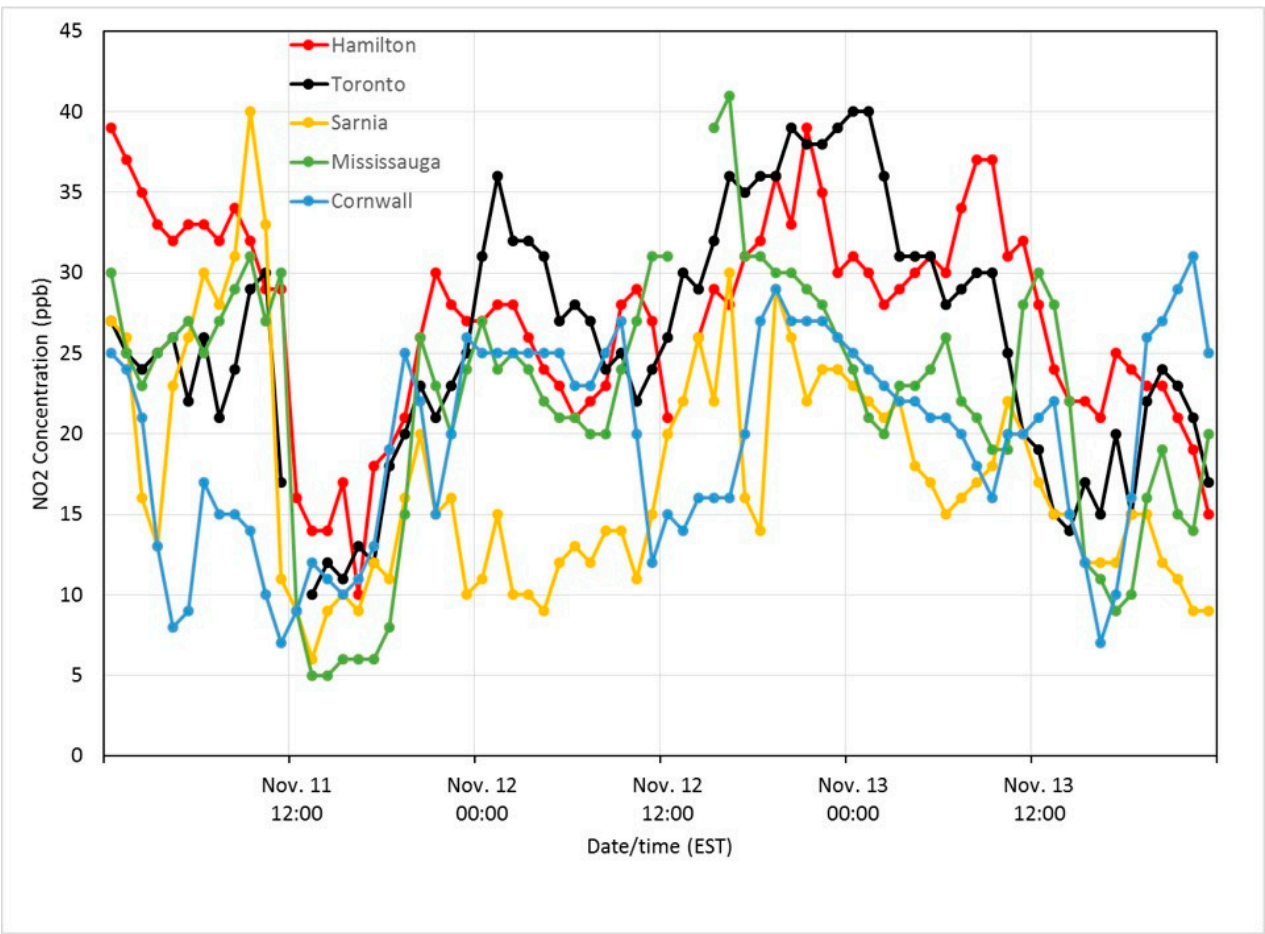

Figure 13. $\mathrm{NO}_{2}$ hourly concentrations at various locations, 11-13 November 2010. 


\subsection{Example of 1 July 2013}

\subsubsection{Introduction}

This is an example of a block pattern that caused wildfire smoke from forest fires in northern Quebec to move southwestward to northeastern Ontario, which resulted in adverse air quality due to high concentrations of PM2.5 in populated regions of southern, central and eastern Ontario. In this example, the pollutant that was significantly affected by the smoke was PM2.5. Although forest fires can cause significant $\mathrm{O}_{3}$ concentrations over downwind regions by providing VOC precursors [37,38], the concentrations of $\mathrm{O}_{3}$ and $\mathrm{NO}_{2}$ were much less affected in this example and did not increase significantly above background levels.

\subsubsection{Synoptic Description}

A strong ridge at the $500 \mathrm{hPa}$ level developed over the northern Atlantic Ocean during late June 2013 and caused a trough to temporarily stall over the southern Great Lakes region during the period 28-30 June, following a trough split event in which the southern part of the trough remained over eastern North America. The blocking Atlantic ridge and trough split can be seen in the pattern of $500 \mathrm{hPa}$ GPH plotted in Figure 14. At lower levels, the trough was also a persistent feature for several days, as seen in the charts of composite mean $850 \mathrm{hPa} \mathrm{GPH}$ and winds (illustrated in the supplement) which show a distinct trough east of, and a ridge west of, longitude 90 degrees west. In the region near James Bay, circulation around the trough resulted in winds oriented anomalously from northeast toward southwest. Smoke from wildfires in northwestern Quebec that had been flowing eastward (in typical westerly flow) became transported southwestward to populated regions of southern and eastern Ontario. The direction of smoke transport can be seen in the NASA Worldview map (illustrated in the supplement) which shows fire hotspots southeast of Hudson Bay and smoke plumes spreading southwestward over northern Ontario. The pattern of MSLP during the period 1-3 July is shown in the supplement and shows the low pressure trough at the surface gradually diminishing after 2 July.
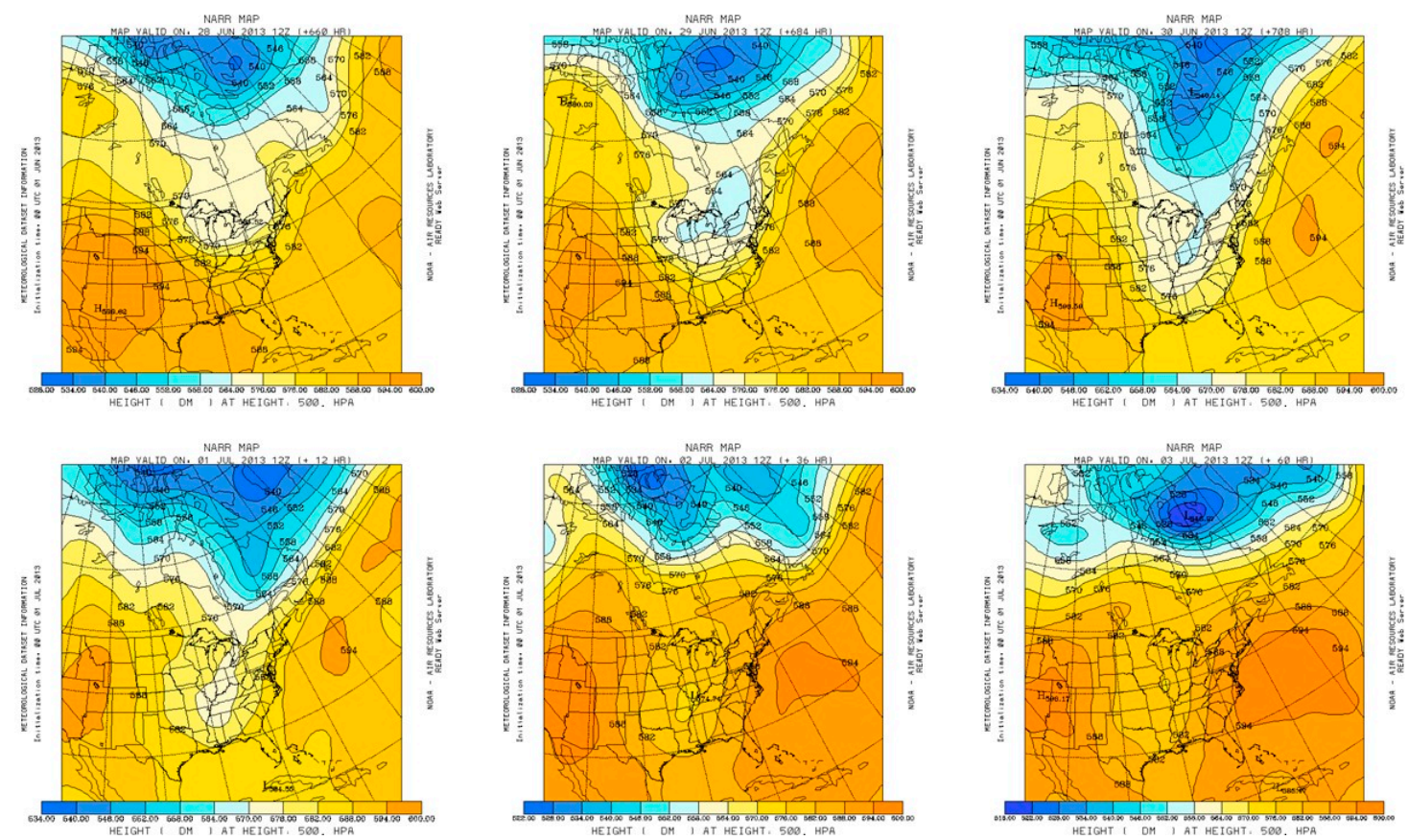

Figure 14. Daily $500 \mathrm{hPa}$ GPH from 28 June (upper left) to 3 July (lower right), 2013. Credit: NOAA ARL. 


\subsubsection{Discussion}

Smoke plumes reached southern, central and eastern Ontario during 30 June and 1 July, and concentrations of PM2.5 measured at air monitoring stations in various cities and towns in these regions increased sharply as seen in the chart of concentrations plotted in Figure 15. Concentrations increased well above 50 micrograms per cubic meter at many locations and above 70 micrograms per cubic meter at several locations.

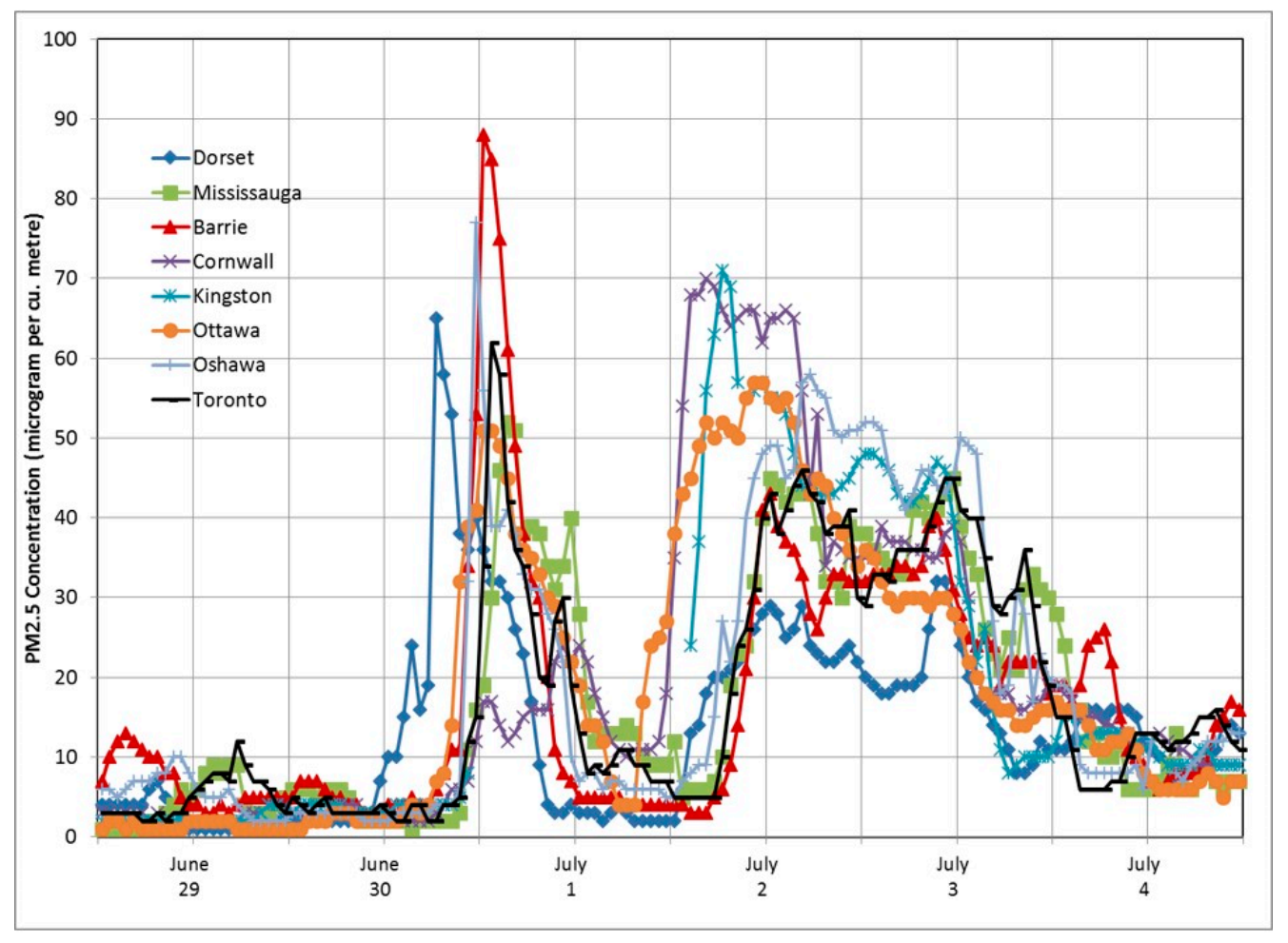

Figure 15. PM2.5 hourly concentrations, 29 June-4 July 2013. Dates are shown at Local Time 12:00.

During 1 July, the trough moved eastward from Quebec and northeastern Ontario while a high pressure ridge spread eastward over northern Ontario and then merged with the ridge over the western Atlantic. The low pressure trough south of the Great Lakes region weakened and diminished during 2 July as the upper-level low diminished. Wind streamlines over southern and eastern Ontario originated from northeastern Ontario during 1 July and then from the state of New York by the morning of 2 July. The change in source region from smoke-filled air in northeastern Ontario and Quebec, to the unpolluted air over New York State, resulted in PM2.5 concentrations decreasing over southern and eastern Ontario during 2-3 July as daytime winds and convection provided dispersion of the smoke from the boundary layer. Charts showing MSLP and streamlines at the $925 \mathrm{hPa}$ level (approximately representing the top of the boundary layer, although $850 \mathrm{hPa}$ streamlines are similar) are shown in the supplement.

\subsubsection{Summary}

In this example, a blocking pattern over the north Atlantic resulted in a significant change in direction of flow over northern Ontario which resulted in wildfire smoke flowing southward over populated regions and caused adversely high concentrations of PM2.5 in numerous locations for several days. 


\subsection{Example of 15 July 2013}

\subsubsection{Introduction}

This event is an example of a westward-building ridge from the Atlantic coast to the southern Great Lakes region that resulted in a ridge becoming nearly stationary over southern Ontario. Along with the nearly stationary and persistent ridge, lake breeze effects caused anomalously high $\mathrm{O}_{3}$ concentrations at air quality monitoring stations in the lakeshore regions, but not over a widespread area of southern Ontario. This was an example of a retrogressing ridge, in contrast to the more typical pattern of the westerly flow of ridges, troughs and fronts progressing eastward across Ontario and the typical pattern of high $\mathrm{O}_{3}$ concentrations which develop over regions south and west of southern Ontario during summer and then spread northeastward over southern Ontario.

\subsubsection{Synoptic Description}

At the $500 \mathrm{hPa}$ level, an upper-level trough was nearly stationary over the mid-Atlantic Ocean during 12-15 July, while a ridge strengthened west of the trough over the western Atlantic Ocean. A trough was over Ontario during 11 July, moved eastward from northern Ontario during 12 July, and split into northern and southern sections along the west side of the strong ridge east of the Atlantic coast. The southern portion of the trough merged with the weakening wave that was the remnant of Tropical Storm Chantal, which weakened below tropical storm strength on 10 July (south of Hispaniola in the Caribbean Sea) and then continued moving northwestward over the southeastern US during 11-12 July. The combined trough remained over the eastern US during 12-13 July, then migrated westward to the southern Great Plains region (primarily the states of Texas and Oklahoma) during 15 July. The ridge spread westward from the western Atlantic Ocean to the Great Lakes region during 13-16 July following the westward migration of the trough that was over the eastern US. The progression of ridges and troughs is shown in Figure 16. At the $850 \mathrm{hPa}$ level, temperatures over southern Ontario increased from $14^{\circ} \mathrm{C}$ during 13 July to $17^{\circ} \mathrm{C}$ during 15 July and continued to increase to $20^{\circ} \mathrm{C}$ during 19 July and then eventually decreased during 20 July. Temperatures at the $850 \mathrm{hPa}$ level are shown in the supplement.
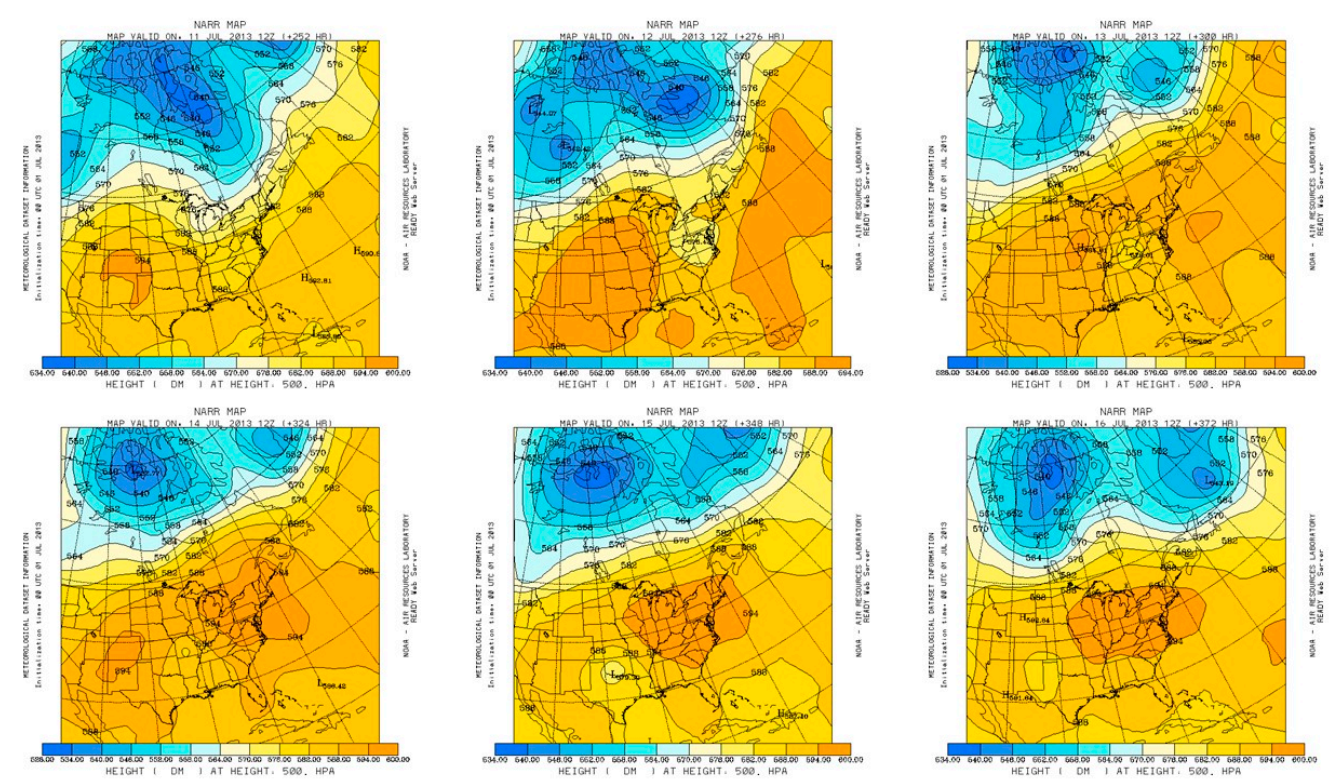

Figure 16. $500 \mathrm{hPa}$ GPH pattern, 11 July (upper left) to 16 July (lower right), 2013. Credit: NOAA ARL.

At the surface, a high pressure ridge spread westward from the Atlantic coast to the Great Lakes region during 14-15 July and then diminished in strength and eventually moved eastward from 
southern Ontario during 18 July. Mean sea-level pressure plots are shown in the supplement. Lake breezes developed as a result of temperature differences and were significant for the ground-level $\mathrm{O}_{3}$ concentrations near lakeshore locations. During 15 July, the high pressure ridge over southern Ontario resulted in a weak pressure gradient with light winds and sunny skies. As in the typical lake-breeze development conditions, the land surfaces were cooler than the surface of Lake Ontario during the morning and a weak meso-high developed over the land during the early morning period, with a corresponding meso-low over the warmer surface of Lake Ontario. During the afternoon, the land surfaces became warmer than the lake surface, a meso-high was over the lakes, and meso-low over the land surfaces. This pressure couplet resulted in on-shore lake breezes during the afternoon, transporting $\mathrm{O}_{3}$-rich air in the marine layer inland within the thermal internal boundary layer to the air quality monitoring stations near the lakeshore. The westward-moving ridge allowed winds at the $850 \mathrm{hPa}$ level to become optimally situated for coupling of the surface-level onshore flow component of the developing lake breeze circulation cell with winds near the top of the circulation.

Winds at the $850 \mathrm{hPa}$ level were an important factor. During $14 \mathrm{July}$, the $850 \mathrm{hPa}$ ridge center was east of the Atlantic coast (near New Jersey) and winds at the $850 \mathrm{hPa}$ level were southwesterly across western Lake Ontario (approximately parallel to the north shore) and not contributing to lake breeze circulation. During 15 July, the ridge center was south of Lake Erie (over Ohio) and winds at the $850 \mathrm{hPa}$ level were northerly across western Lake Ontario, providing an upper flow nearly directly opposite to the onshore surface-level flow. The ridge moved westward to Indiana during 16 July and caused $850 \mathrm{hPa}$-level winds to be northwesterly across western Lake Ontario. As a result, conditions continued to be ideal for coupling between the afternoon lake breeze circulation cell and the circulation above the atmospheric boundary layer. Charts showing the position of the ridge and wind streamlines at the $850 \mathrm{hPa}$ level for 14-16 July are shown in the supplement and illustrate the upper wind directions becoming optimum for lake breeze formation as the ridge moved westward.

The mesoscale high and low pressure distribution during the afternoons of 15 and 16 July that developed optimum conditions for lake breeze circulations are illustrated in the MSLP charts for 14-16 July in the supplement, with local high pressure over the lakes and lower pressure over the land surface north of Lake Ontario during the afternoons (and opposite during the mornings) of 14 and 15 July. A chart showing MSLP in intervals of $0.2 \mathrm{hPa}$ in Figure 17 shows the relative high pressure over western Lake Ontario and lower pressure over adjacent land areas north of the lake during the afternoon of $15 \mathrm{July}$, which caused onshore winds from south to north over the north shore of the lake, toward the populated cities of Ontario. The chart of wind streamlines at the $850 \mathrm{hPa}$ level in Figure 18 for the same time shows that upper winds were in the opposite direction to low-level winds, which resulted in optimum conditions for development of the lake breeze circulation. Sunny skies over Lake Ontario contributed to $\mathrm{O}_{3}$ formation in the lowest marine layer (where the shallow stable cool layer, cloudless skies and presence of organic compounds and other $\mathrm{O}_{3}$ precursors provided optimum $\mathrm{O}_{3}$ formation conditions) and can be seen in the visible-wavelength satellite image (in the supplement).

\subsubsection{Discussion}

The $\mathrm{O}_{3}$ concentrations increased above $80 \mathrm{ppb}$ at cities near the Lake Ontario shoreline during 15 and 16 July and remained much lower at other locations in southern Ontario. The one-hour $\mathrm{O}_{3}$ concentrations are plotted on the maps for late afternoon of 15 and 16 July in Figure 19 and illustrate the significantly higher $\mathrm{O}_{3}$ concentrations near the lakeshore than at inland locations. The air quality monitoring locations close to the western Lake Ontario shoreline include Hamilton, Burlington, Oakville, Mississauga and Toronto, where $\mathrm{O}_{3}$ increased to maximum hourly concentrations of 86, $79,101,83$ and $87 \mathrm{ppb}$ respectively during 15 July. Other monitoring stations in southern Ontario reported significantly lower concentrations and were generally $60 \mathrm{ppb}$ or lower. Newmarket, $44 \mathrm{~km}$ north of Toronto, recorded a maximum of $59 \mathrm{ppb}$ and Oshawa, $50 \mathrm{~km}$ northeast of Toronto, recorded a maximum of $60 \mathrm{ppb}$. During the afternoon of $16 \mathrm{July}$, similar conditions occurred except that the region of high $\mathrm{O}_{3}$ concentrations near western Lake Ontario shifted slightly eastward to include Oshawa. 
Maximum hourly $\mathrm{O}_{3}$ concentrations at locations in the region of high $\mathrm{O}_{3}$ included $94 \mathrm{ppb}$ (Oakville), 92 (Burlington), 96 (St. Catharines), 90 (Toronto) and 96 (Oshawa). Elsewhere across southern or eastern Ontario, most locations (except for two) recorded maximum concentrations less than $70 \mathrm{ppb}$. Neither $\mathrm{NO}_{2}$ nor PM2.5 concentrations increased significantly and are not shown.

This example is significantly different from the summertime example of 22-25 June 2003, in which a widespread polluted airmass spread northeastward over southern Ontario in the conditions of light southwesterly flow that are often associated with the west side of a large high pressure ridge that moves eastward over the eastern US. In contrast, this is an example of unusual block-induced conditions that became suitable for development of high $\mathrm{O}_{3}$ concentrations over a specific region while much lower $\mathrm{O}_{3}$ concentrations remained over most of Ontario. The regions with strong $\mathrm{O}_{3}$ formation were the lakeshore regions, where the shallow marine layer above the lake surface of Lake Ontario was likely enriched with an offshore flow of urban air polluted with precursors. The local formation of $\mathrm{O}_{3}$ over the lake surface from precursors emitted from industrial and urban sources in the populated regions around western Lake Ontario is a reasonable explanation because of the lack of advection of air enriched with $\mathrm{O}_{3}$ or precursors. Back trajectories ending at Toronto, and maps showing the absence of significant $\mathrm{O}_{3}$ during the days before 15 and 16 July in regions upstream from Toronto, are shown in the supplement. The retrogressing ridge provided optimum conditions for lake breeze development and onshore flow of the marine layer with high $\mathrm{O}_{3}$ concentrations onto populated regions of the north shore of western Lake Ontario, while inland locations experienced significantly lower $\mathrm{O}_{3}$ concentrations. While it is not a typical development, this example illustrates the unusual effects that may develop in the situation of a westward-moving tropical storm remnant and retrogressing ridge.

\subsubsection{Summary}

Conditions suitable for high $\mathrm{O}_{3}$ concentrations to develop at Lake Ontario shoreline locations were caused by a westward-building ridge that was blocked by a mid-Atlantic trough which remained nearly stationary during the days preceding the $15-16 \mathrm{July}_{3}$ episode. Significant factors that contributed to causing high $\mathrm{O}_{3}$ concentrations near lakeshore locations were the winds at the $850 \mathrm{hPa}$ level and the coupling of these winds with the diurnal lake breeze circulation.

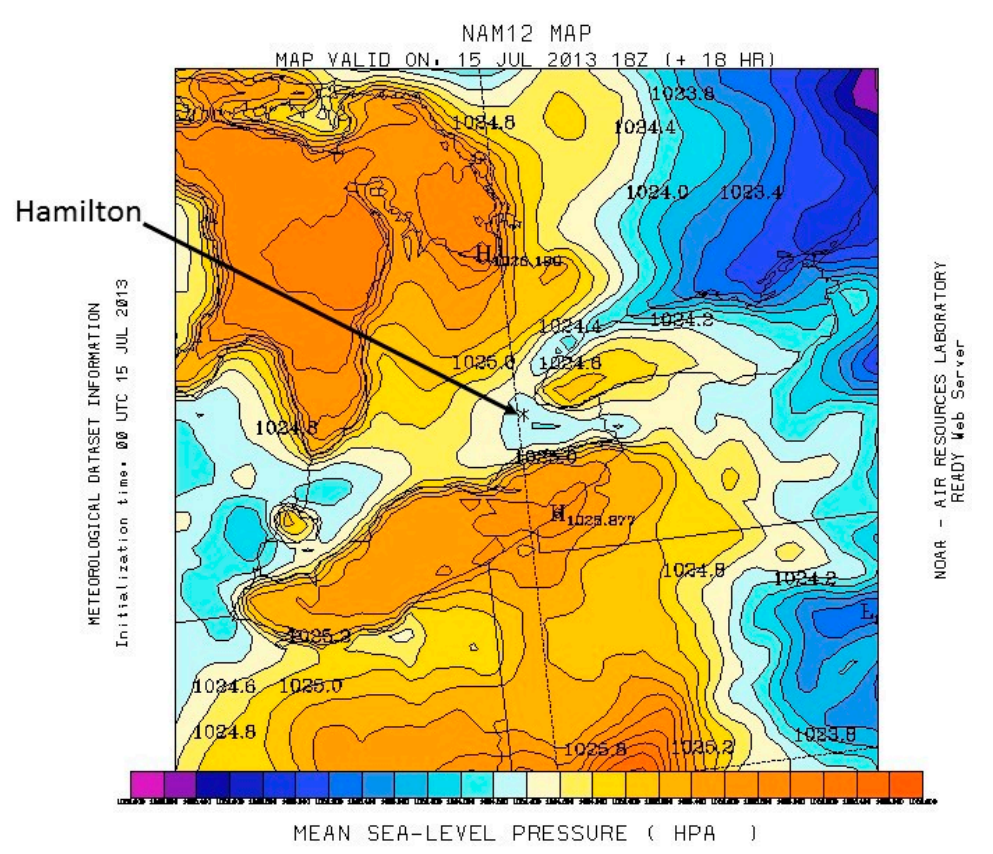

Figure 17. MSLP (shown at $0.2 \mathrm{hPa}$ intervals), 15 July 2013, EDT 14:00, with the arrow marking Hamilton, Ontario. Credit: NOAA ARL. 


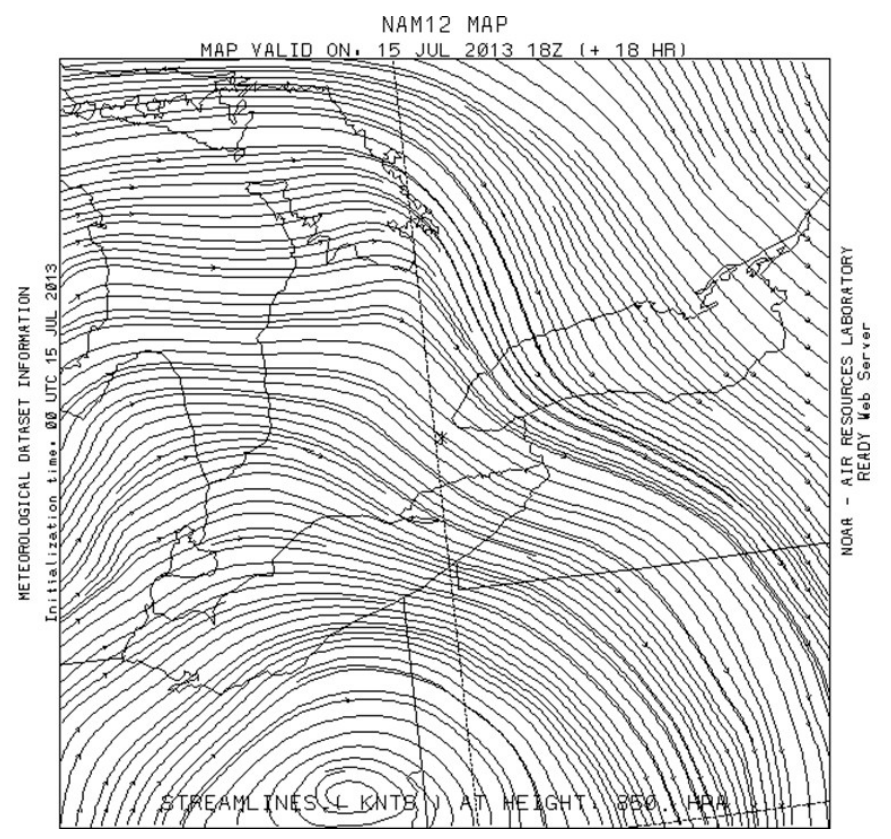

Figure 18. Streamlines at $850 \mathrm{hPa}$ level, 15 July 2013, EDT 14:00. Credit: NOAA ARL.

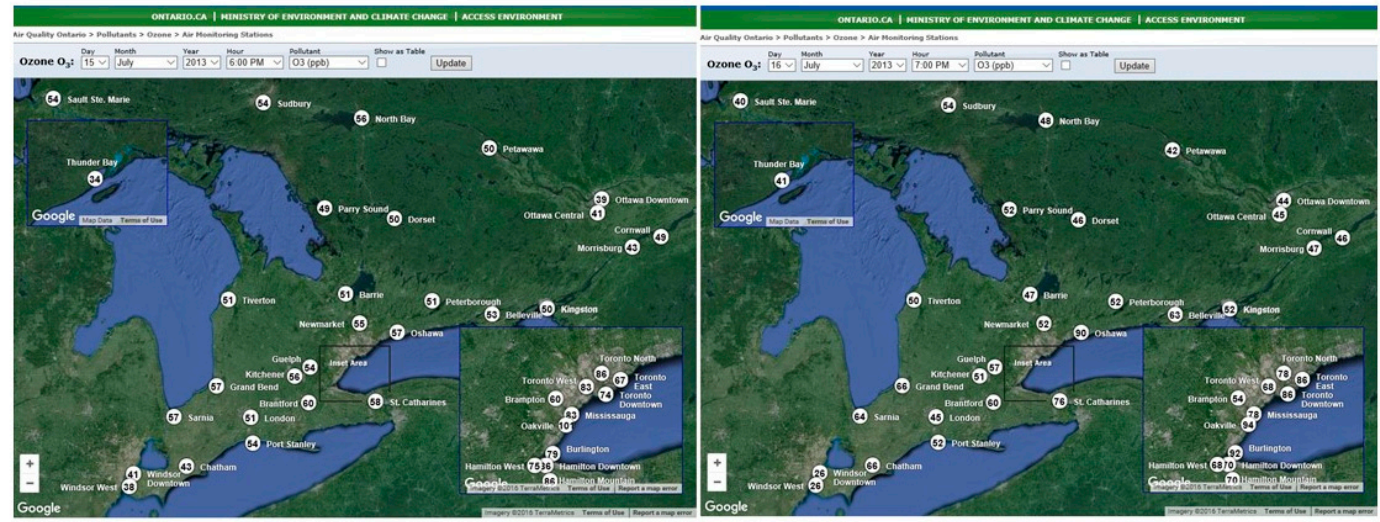

Figure 19. One-hour $\mathrm{O}_{3}$ concentrations at local time 18:00 15 July (left) and local time 19:00 16 July (right), 2013. Credit: Ontario Ministry of Environment and Climate Change, website: http: / / www.airqualityontario.com/ (last accessed 9 January 2017).

\section{Conclusions}

Examples of regional-scale blocking weather patterns lasting several days have been used to illustrate how blocking can alter the typical circulation, transport and dispersion patterns that affect potential pollutants. Blocking-induced air quality episodes may occur during any season and affect various regions of Ontario. Local effects include weakening dispersion of the boundary layer at some locations and $\mathrm{O}_{3}$-enriched marine layers affecting lakeshore areas during specific meteorological conditions conducive for lake breeze circulations.

A concise summary of the examples studied in this survey is shown in Table 2. The many blocking patterns that have been seen to cause increasing pollutant concentrations generally fit into the categories listed in the table, but variations occur each year due to local meteorological factors (including mesoscale weather systems and processes) and variations in emissions (such as from electrical generation and heating facilities) during different temperature and weather conditions. Although the block effects in Table 2 occur several times each year to some degree during most 
years, yearly variations are normal and make it difficult to quantify the effects that could help to estimate trends. Year-to-year variation will continue because of the variations in synoptic-scale blocking patterns (as noted in the Introduction) and the normal yearly variations in temperature and precipitation patterns that result in differing weather situations in Ontario (and more generally, many regions of North America) each month of each year.

Table 2. Table of block types and effects on pollutants.

\begin{tabular}{|c|c|c|c|}
\hline Block Type & Season & Pollutants Affected & Notes \\
\hline $\begin{array}{l}\text { Ridge over southern } \\
\text { Ontario-eastern U.S. }\end{array}$ & summer & $\mathrm{O}_{3}, \mathrm{NO}_{2}, \mathrm{PM} 2.5$ & $\begin{array}{l}\text { Hot, humid, stagnant weather } \\
\text { conditions are typical }\end{array}$ \\
\hline $\begin{array}{l}\text { Ridge over southern } \\
\text { Ontario-eastern U.S. }\end{array}$ & winter & $\mathrm{PM} 2.5, \mathrm{NO}_{2}$ & $\begin{array}{l}\text { Important when a block persists long } \\
\text { enough to cause stagnating conditions }\end{array}$ \\
\hline $\begin{array}{l}\text { Ridge over southern } \\
\text { Ontario-eastern U.S. }\end{array}$ & summer & $\mathrm{O}_{3}$ & $\begin{array}{l}\text { Retrogressing ridge over southern } \\
\text { Ontario may result in enhanced } \mathrm{O}_{3} \\
\text { formation in near-lake marine layers } \\
\text { and strong lake breeze circulations }\end{array}$ \\
\hline $\begin{array}{l}\text { Mesoscale ridge over } \\
\text { southern Ontario }\end{array}$ & $\begin{array}{l}\text { Autumn (during periods } \\
\text { when air temperatures over } \\
\text { land and lakes are similar) }\end{array}$ & $\mathrm{PM} 2.5, \mathrm{NO}_{2}$ & $\begin{array}{l}\text { Coincides with nocturnal inversions } \\
\text { persisting during the morning (or day) } \\
\text { and fog which may contribute to PM2.5 } \\
\text { formation and restrict insolation }\end{array}$ \\
\hline $\begin{array}{l}\text { Low pressure trough over } \\
\text { southern Great Lakes region }\end{array}$ & $\begin{array}{l}\text { Summer (during active } \\
\text { wildfire periods) }\end{array}$ & PM2.5 (sometimes $\mathrm{O}_{3}, \mathrm{NO}_{2}$ ) & Dependent on locations of wildfires \\
\hline
\end{tabular}

Effects on air quality include adversely high concentrations of pollutants including $\mathrm{O}_{3}, \mathrm{NO}_{2}$ and PM2.5 which may develop from long-range transport of precursors or from emissions from vehicles, manufacturing, electrical generating and other sources typical for a particular city, town or region. The adverse pollutant concentrations may be single-day events or multi-day episodes. The episodes of deteriorating air quality may affect widespread regions of southern Ontario, or only affect single cities or towns where local meteorological factors combine to cause stagnation (although all of the examples illustrated above show adverse effects on air quality at multiple locations).

Future changes in climate, whether trending toward warmer or cooler conditions in southern Ontario, may result in changes in scale, frequency and duration of blocking patterns. Future work in this field could use detailed modelling simulations of some interesting block-induced AQ episodes to examine and possibly quantify the effects of emissions, precursors and fine-scale meteorology, as well as of larger-scale phenomena such as hemispheric circulation patterns and climate change.

A reasonable projection for the future is that the unpredictability of the occurrences and durations of blocking weather patterns will require forecasters to continue to be alert for developing block patterns that may result in adverse effects on society.

Supplementary Materials: The following are available online at http://www.mdpi.com/2073-4433/9/6/226/s1, Figure S1: Sea surface temperature anomaly, 21 June 2003. Figure S2: Composite mean MSLP, 21-25 June 2003. Figure S3: Upper-air soundings at Detroit MI, 23 June 2003. Figure S4: Upper-air soundings for Buffalo NY, 23 June 2003. Figure S5: NARR weather at Windsor during 23-26 June 2003. Figure S6: Maximum daily 1-h ozone concentrations during the period May-August 2003. Images supporting the example of 2-7 February 2005. Figure S7: $500 \mathrm{hPa}$ GPH from 2 to 7 February 2005. Figure S8: 500 hPa GPH mean composite anomaly, 1-6 February 2005. Figure S9: MSLP pattern, 1 to 6 February 2005. Figure S10: NARR weather at Sarnia, Ontario during 1-4 February 2005. Images supporting the example of 12 November 2010. Figure S11: 850 hPa temperature, 12 November 2010. Figure S12: Upper air sounding for Buffalo NY, 12Z, 12 November 2010. Figure S13: Great Lakes surface temperatures, 2010. Figure S14: MSLP, 12 November, 12Z, 2010. Images supporting the example of 1 July 2013. Figure S15: Composite mean 850 hPa GPH 28 June-2 July 2013. Figure S16: Winds and GPH at $850 \mathrm{hPa}$ level 29 June 2013. Figure S17: NASA Worldview true color map showing detected fires, 29 June 2013. Figure S18: MSLP pattern during 1 July 00Z to 3 July 12Z, 2013. Figure S19: Streamline pattern at $925 \mathrm{hPa}$ level during 2-3 July 2013. Images supporting the example of 15 July 2013 Figure S20: Temperatures at $850 \mathrm{hPa}$ level, 14 to 19 July, 2013. Figure S21: MSLP pattern, 14 to 19 July 2013. Figure S22: $850 \mathrm{hPa}$ GPH with streamlines, 14 to 16 July 2013. Figure S23: MSLP, July $1409 Z$ and 18Z, 15 and 16, 2013. Figure S24: Visible-wavelength satellite, afternoon of 15 July 2013. Figure S25: 48-h Back trajectories ending at Toronto on afternoon of 15 July 2013. Figure S26: 48-h Back trajectories ending at Toronto on afternoon of 16 July 2013. Figure S27: Peak ozone AQI during 13 July 2013. Figure S28: Peak ozone AQI during 14 July 2013. Figure S29: Peak ozone AQI during 15 July 2013. Figure S30: Peak ozone AQI during 16 July 2013. 
Conflicts of Interest: The author declares no conflict of interest.

\section{References}

1. Carrera, M.L.; Higgins, R.W.; Kousky, V.E. Downstream weather impacts associated with atmospheric blocking over the northeast Pacific. J. Clim. 2004, 17, 4823-4839. [CrossRef]

2. Charney, J.G.; Shukla, J.; Mo, K.C. Comparison of a Barotropic Blocking Theory with Observation. J. Atmos. Sci. 1981, 38, 762-779. [CrossRef]

3. Barriopedro, D.; Garcia-Herrera, R.; Lupo, A.; Hernandez, E.A. Climatology of northern hemisphere blocking. J. Clim. 2006, 19, 1042-1063. [CrossRef]

4. Grose, W.L.; Hoskins, B.J. On the influence of orography on large-scale atmospheric flow. J. Atmos. Sci. 1979, 36, 223-234. [CrossRef]

5. Hakkinen, S.; Rhines, P.; Worthen, D. Atmospheric blocking and Atlantic Multidecadal Ocean variability. Science 2011, 334, 655-659. [CrossRef] [PubMed]

6. Peings, Y.; Magnusdottir, G. Forcing of the wintertime atmospheric circulation by the multidecadal fluctuations of the North Atlantic ocean. Environ. Res. Lett. 2014, 9, 034018. [CrossRef]

7. Shabbar, A.; Huang, J.; Higuchi, J. The relationship between the wintertime north Atlantic oscillation and blocking episodes in the north Atlantic. Int. J. Climatol. 2001, 21, 355-369. [CrossRef]

8. Barriopedro, D.; Calvo, N. On the relationship between ENSO, stratospheric sudden warmings, and blocking. J. Clim. 2014, 27, 4704-4720. [CrossRef]

9. Cassou, C. Intraseasonal interaction between the Madden-Julian Oscillation and the north Atlantic Oscillation. Nat. Lett. 2008, 455, 523-527. [CrossRef] [PubMed]

10. Henderson, S.A.; Maloney, E.D.; Barnes, E.A. The Influence of the Madden-Julian Oscillation on northern hemisphere winter blocking. J. Clim. 2016, 29, 4597-4616. [CrossRef]

11. Barriopedro, D.; García-Herrera, R.; Huth, R. Solar modulation of Northern Hemisphere winter blocking. J. Geophys. Res. Atmos. 2008, 113, D14118. [CrossRef]

12. Mitchell, D.M.; Gray, L.J.; Anstey, J.; Baldwin, M.P.; Charlton-Perez, A.J. The influence of stratospheric vortex displacements and splits on surface climate. J. Clim. 2013, 26, 2668-2682. [CrossRef]

13. Glecker, P.J.; Santer, B.D.; Domingues, C.M.; Pierce, D.W.; Barnett, T.P.; Church, J.A.; Taylor, K.E.; AchutaRao, K.M.; Boyer, T.P.; Ishii, M.; et al. Human-induced global ocean warming on multidecadal timescales. Nat. Clim. Chang. 2012, 2, 524-529. [CrossRef]

14. Meehl, G.A.; Washington, W.M.; Wigley, T.M.L.; Arblaster, J.M.; Dai, A. Solar and Greenhouse Gas Forcing and Climate Response in the Twentieth Century. J. Clim. 2003, 16, 426-444. [CrossRef]

15. Radel, G.; Mauritsen, T.; Stevens, B.; Dommenget, D.; Matei, D.; Bellomo, K.; Clement, A. Amplification of El Nino by cloud longwave coupling to atmospheric circulation. Nat. Geosci. 2016, 9, 106-110. [CrossRef]

16. Clement, A.C.; Burgman, R.; Norris, J.R. Observational and model evidence for positive low-level cloud feedback. Science 2009, 324, 450-464. [CrossRef] [PubMed]

17. Sutton, R.T.; Allen, M.R. Decadal predictability of North Atlantic sea surface temperature and climate. Nature 1997, 388, 563-567. [CrossRef]

18. Commou, D.; Lehmann, J.; Beckmann, J. The weakening summer circulation in the northern hemisphere mid-latitudes. Sci. Express 2015, 348, 324-327. [CrossRef] [PubMed]

19. Francis, J.; Skific, N. Evidence linking rapid Arctic warming to mid-latitude weather patterns. Philos. Trans. R. Soc. A 2015, 373, 20140170. [CrossRef] [PubMed]

20. Barnes, E. Revisiting the evidence linking Arctic amplification to extreme weather in midlatitudes. Geophys. Res. Lett. 2013, 40, 4734-4739. [CrossRef]

21. Kennedy, D.; Parker, T.; Woolings, T.; Harvey, B.; Shaffrey, L. The response of high-impact blocking weather systems to climate change. Geophys. Res. Lett. 2016, 43, 7250-7258. [CrossRef]

22. Rex, D.F. Blocking action in the middle troposphere and its effect upon regional climate. 1. An aerological study of blocking action. Tellus 1950, 2, 196-211. [CrossRef]

23. Treidl, R.; Birch, E.; Sajecki, P. Blocking action in the northern hemisphere: A climatological study. Atmos. Ocean 1981, 19, 1-23. [CrossRef]

24. White, W.B.; Clark, N.E. On the development of blocking ridge activity over the central North Pacific. J. Atmos. Sci. 1975, 32, 489-502. [CrossRef] 
25. Dole, R.M.; Gordon, N.D. Persistent anomalies of the extra-tropical Northern Hemisphere wintertime circulation: Geographical distribution and regional persistence characteristics. Mon. Weather Rev. 1983, 111, 1567-1586. [CrossRef]

26. Lejenas, H.; Oakland, H. Characteristics of northern hemisphere blocking as determined from long time series of observational data. Tellus 1983, 35A, 350-362. [CrossRef]

27. Tibaldi, S.; Molteni, F. On the operational predictability of blocking. Tellus 1990, 42A, 343-365. [CrossRef]

28. McKendry, I.G. Synoptic circulation and summertime ground-level ozone concentrations at Vancouver, British Columbia. J. Appl. Meteorol. 1994, 33, 627-641. [CrossRef]

29. Shahgedanova, M.; Burt, T.P.; Davies, T.D. Synoptic climatology of air pollution in Moscow. Theor. Appl. Climatol. 1998, 51, 85-102. [CrossRef]

30. Jiang, N.; Dirks, K.; Luo, K. Effects of local, synoptic and large-scale climate conditions on daily nitrogen dioxide concentrations in Auckland, New Zealand. Int. J. Climatol. 2013, 34, 1883-1897. [CrossRef]

31. Kampa, M.; Castanas, E. Human health effects of air pollution. Environ. Pollut. 2008, 151, 362-367. [CrossRef] [PubMed]

32. Holloway, A.M.; Wayne, R.P. Atmospheric Chemistry; RCS Publishing: Cambridge, UK, 2010; pp. $101-120$. ISBN 978-1-84755-807-7.

33. Jacob, D.J. Introduction to Atmospheric Chemistry; Princeton University Press: Princeton, NJ, USA, 1999; pp. 200-216. ISBN 0-691-00185-5.

34. Brook, J.R.; Makar, P.A.; Sills, D.; Hayden, K.L.; McLaren, R. Exploring the nature of air quality over southwestern Ontario: Main findings from the Border Air Quality and Meteorology Study. Atmos. Chem. Phys. 2013, 13, 10461-10482. [CrossRef]

35. Yap, D.; Reid, N.; De Brou, G.; Bloxam, R. Transboundary Air Pollution in Ontario. Ontario Ministry of the Environment. 2005. Available online: http://www.airqualityontario.com/downloads / TransboundaryAirPollutionInOntario2005.pdf (accessed on 14 May 2018).

36. Kalnay, E.; Kanamitsu, M.; Kistler, R.; Collins, W.; Deaven, D.; Gandin, L.; Iredell, M.; Saha, S.; White, G.; Woollen, J.; et al. The NCEP/NCAR 40-Year Reanalysis Project. Bull. Am. Meteorol. Soc. 1996, 77, 437-471. [CrossRef]

37. Dempsey, F. Forest Fire Effects on Air Quality in Ontario: Evaluation of Several Recent Examples. Bull. Am. Meteorol. Soc. 2013, 94, 1059-1064. [CrossRef]

38. Pfister, G.G.; Wiedinmyer, C.; Emmons, L.K. Impacts of the fall 2007 California wildfires on surface ozone: Integrating local observations with global model simulations. Geophys. Res. Lett. 2008, 35, L19814. [CrossRef] 